\title{
Miranda
}

Revue pluridisciplinaire du monde anglophone /

Multidisciplinary peer-reviewed journal on the English-

speaking world

$17 \mid 2018$

Paysages et héritages de David Bowie

\section{Performing Mrs Dalloway (1925)}

\section{Jean-Rémi Lapaire}

\section{OpenEdition}

\section{Journals}

\section{Electronic version}

URL: http://journals.openedition.org/miranda/14255

DOI: 10.4000/miranda.14255

ISSN: 2108-6559

\section{Publisher}

Université Toulouse - Jean Jaurès

\section{Electronic reference}

Jean-Rémi Lapaire, "Performing Mrs Dalloway (1925)", Miranda [Online], 17 | 2018, Online since 02

October 2018, connection on 16 February 2021. URL: http://journals.openedition.org/miranda/14255 ; DOI: https://doi.org/10.4000/miranda.14255

\section{This text was automatically generated on 16 February 2021.}

\section{(9) $\odot \Theta$}

Miranda is licensed under a Creative Commons Attribution-NonCommercial-NoDerivatives 4.0 International License. 


\title{
Performing Mrs Dalloway (1925)
}

\author{
Jean-Rémi Lapaire
}

\section{Before the curtain rises}

One writes for a very few people, who understand. ${ }^{1}$

A glorious June day in 1923: the "hot sun"; the "humming traffic "; the people "walking the streets of London"; the "sound of Big Ben striking the half hour." Clarissa Dalloway has "just broken into her fifty-second year." she is giving a party in the evening, which the Prime Minister is due to attend. She decides on a dress suitable for the occasion, then goes out to "buy the flowers herself." Meanwhile, Septimus Warren Smith - a delirious, shell-shocked War veteran - receives "messages" from the dead and has hallucinations, severe, painful, ecstatic. The day goes by, and important decisions have to be made. Septimus decides to throw himself out from "the large Bloomsbury lodging house window" - "vigorously, violently" meeting his death in "a suffocation of blackness." Clarissa Dalloway accidentally learns the tragic news during her party - "a very sad case." she cringes, she empathises, she experiences disturbing flashes of self-revelation, yet chooses to remain "the perfect hostess," standing there "in her evening dress" among her guests. Although Clarissa and Septimus do not know each other, their destinies meet and temporarily integrate on that "extraordinary night." 
Figure 1

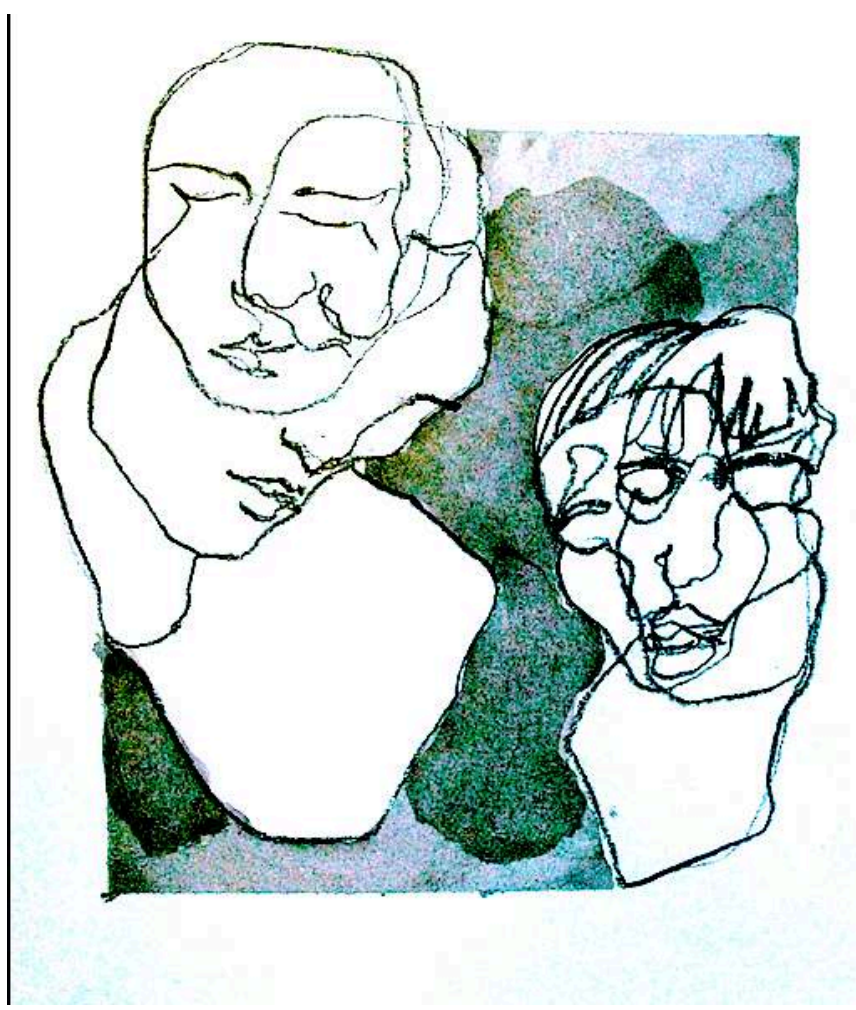

Septimus \& Clarissa Dalloway

(c) Emma Kadraoui

2 The conversion of a "long novel" into a "little contracted play" (Woolf, [1925] 1984: 53) is not a simple matter of size reduction. Contraction (or shortening) requires the ability to grasp essentials, while preserving meaningful aspects of wording and style. Dramatization forces the scriptwriter, director and actors to reconsider the spatiotemporal frame of the original story and make the necessary syntactic adjustments, like converting free indirect speech into dialogue, verbs of reporting into stage directions, non personal or third person forms into personal statements.

Woolf's narrative "exceeds the boundaries of conventional novelistic form by jumping from perspective to perspective" (Krouse 2006: 16). A tragic chorus was created and "integrated into the fabric of the play" (Weiner 1980: 206). Its 8-12 members express shifting viewpoints on the protagonists: their personality traits, their feelings, and their interactions. Thus "She is at her worst - effusive, insincere" (uttered by an anonymous chorus "voice") echoes Peter's rejection of Clarissa's social ambition and calculated polite behaviour:

'How delightful to see you!' said Clarissa. She said it to every one. How delightful to see you! She was at her worst - effusive, insincere. It was a great mistake to have come. (Mrs Dalloway, [1925] 2013: 156)

The Choir is also in charge of singing the "party song" at the beginning of Act 1, which conveys the low opinion that various characters have of Richard Dalloway's blandness and intellectual ability: "Luv's his daughter / Luv's his dogs / A simple man / Thick in the head! / A politician / Wastin' his life / On politics!"2

Producing a stage adaptation can serve a number of purposes, which may be artistic, recreational or educational. The main objective of Performing Mrs Dalloway was to 
encourage students to engage physically in multimodal acts of literary appreciation. The idea was to stage a short but powerful group performance, with successive tableaux (static or dynamic), expressive pauses, silent kinetic episodes, and dramatic moments. Language learners, at all levels of instruction, were invited to follow Quintilian's method: abridgement and paraphrase. ${ }^{3}$ They condensed and simplified the source text; they reflected and learnt through the medium of "paraphrase" - an activity mistakenly construed as idle imitation. Rewording - free or constrained, creative or imitative - led them to reconsider the relationship between form and meaning. Abridgment forced them to tell what was essential from what was not, what could be inferred from what could not, and justify themselves.

6 I wrote my own script - Performing Mrs Dalloway - along those very lines. Readers will find an annotated copy of the final version in the next section, followed by an analysis of the "creative rewriting" process that I personally engaged in. Language and literature teachers will also find a description of the stage work done with the students at my home university (UBM) and Lycée Bossuet (Condom-en-Armagnac, Gers). I have included student testimonies and a rapid survey of student reception. The article closes with visuals from the public performances that were given in France (European Researcher's Night, Cap Sciences, Bordeaux) and Italy (TILLIT 2018 Festival, Università degli Studi del Piemonte Orientale, Vercelli).

\section{The script}

\section{Characters}

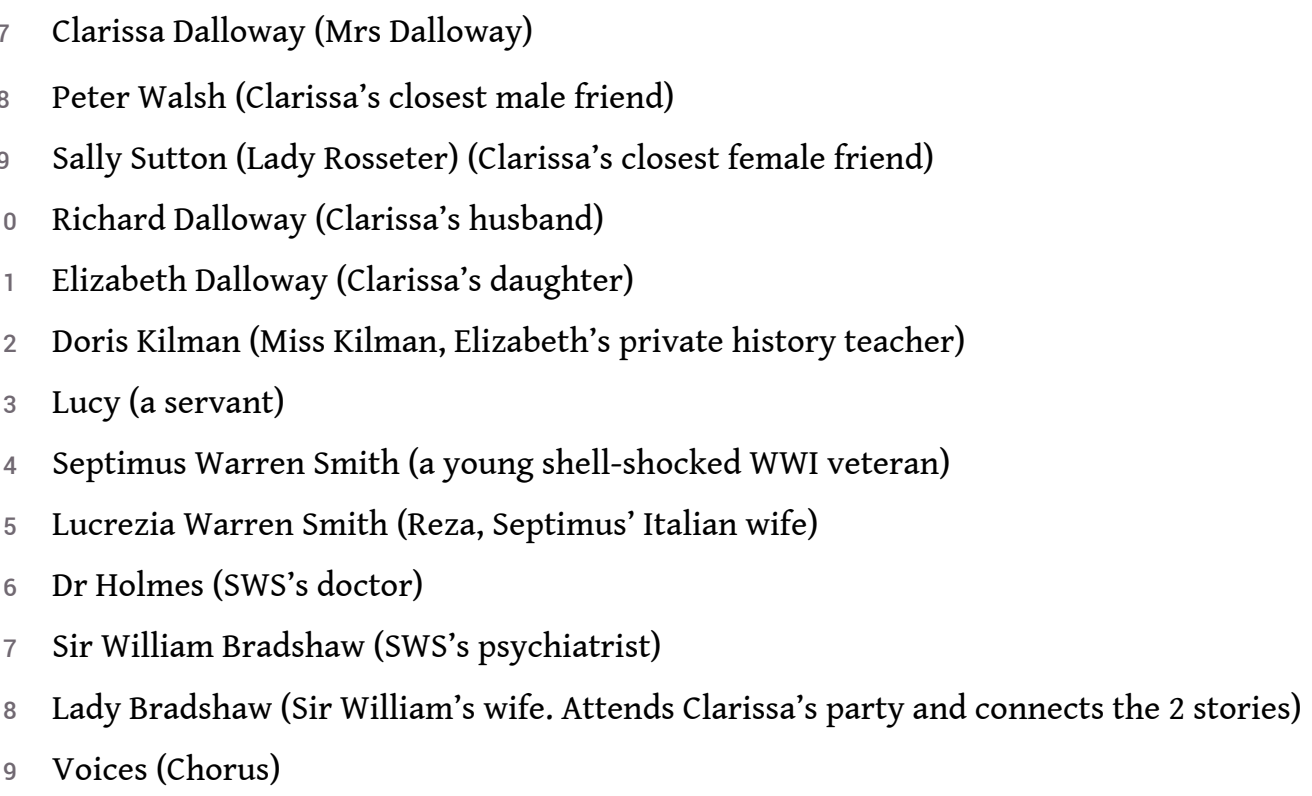

\section{Prologue}

(Groups of soldiers marching, bodies falling to the ground. A pause, a hush. One by one, the bodies slowly rise again). 
CHORUS VOICE: The War is over.

CHORUS VOICE: La guerre est terminée.

CHORUS VOICE: The cabs, the people, and the parks.

CHORUS VoIcE: The ebb and flow of things. ${ }^{5}$

LUCY: Mrs Dalloway said she would buy the flowers herself. ${ }^{6}$

CLARISSA DALLOWAY: What a morning! What a lark! ... What a plunge!

CHORUS VOICE: Mrs Richard Dalloway is giving a party tonight.

CHORUS VOICE: They say the Prime Minister is coming!8

SEPTIMUS: (Seeing things) ${ }^{9}$ Evans, Evans was killed,!

CHORUS VOICE: There in the trenches!

CHORUS VOICE: Just before the Armistice! $!^{10}$

CHORUS VOICE: Every one has friends who were killed in the War! ${ }^{11}$

SEPTIMUS: (Raising his hand like some colossal figure- the giant mourner - then pressing his hands to his forehead, furrows of despair on his cheeks, seeing legions of men prostrate) The mud. The wound. I must tell the whole world!12

CLARISSA DALLOWAY: I'm giving a party tonight. Remember my party! ${ }^{13}$ Remember!

\section{Act 1 - The Party}

CLARISSA DALLOWAY (Speaking to herself, excitedly): I will wear this dress tonight! ${ }^{14}$

CHORUS VOICE: Mrs Dalloway has just broken into her fifty-second year. ${ }^{15}$

CHORUS VOICE: She feels very young; at the same time unspeakably aged.

CHORUS VOICE: She knows nothing - no language, no history.

CHORUS VOICE: Her only gift is knowing people. ${ }^{16}$

CLARISSA DALLOWAY (Speaking to herself, despondently): Oh dear, it is going to be a complete failure. Why am I doing these things? Why? ${ }^{17}$

CHORUS VOICE: What is the sense of Clarissa Dalloway's parties? ${ }^{18}$

CHORUS VOICE: She has always been fond of society. ${ }^{19}$

CHORUS VOICE: They say the Prime Minister is coming! ${ }^{20}$

MISS KILMAN: Are you going to the party tonight? ${ }^{21}$

ELIZABETH DALLOWAY: I suppose so. Mother wants me to. ${ }^{22}$

MISS KILMAN: You mustn't let your mother's parties absorb you! ${ }^{23}$

CHORUS VOICE: The plain ${ }^{24}$ and unhappy Miss Kilman. ${ }^{25}$

CHORUS VOICE: Bitter and burning with fleshly desires! ${ }^{26}$

CHORUS VoICE: Elizabeth Dalloway's private tutor.

CHORUS VOICE: Loves the girl but despises Mrs Dalloway from the bottom of her heart! ${ }^{27}$

CHORUS VOICE: The frightfully clever Doris Kilman! ${ }^{28}$

CHORUS VOICE: With her strong, violent grudge against the world! ${ }^{29}$

MISS KILMAN: I never go to parties. People don't ask me to parties. Why should they ask me? ${ }^{30}$ 


\section{Luv's his wife ${ }^{37}$}

Luv's his daughter

Luv's his dogs. ${ }^{38}$

A simple man,

Thick in the head! ${ }^{39}$

A politician,

Wastin' his life

On politics! ${ }^{40}$ without an invitation! ${ }^{50}$

SALLY: Oh, Clarissa! ${ }^{55}$

PETER WALSH: I should have stayed at home. ${ }^{41}$ What is the sense of these parties, anyway?

${ }^{42}$ Lunching, dining, talking nonsense ${ }^{43}$ The tragedy of married life! ${ }^{44}$

CHORUS VOICE: After five years in India, Peter Walsh is back. ${ }^{45}$

CHORUS VOICE: He's enchanting, perfectly enchanting! ${ }^{46}$

CHORUS VOICE: Early in the nineties, Peter was passionately in love with Clarissa! ${ }^{47}$

CHORUS VOICE: He asked impossible things. He made terrible scenes. ${ }^{48}$

CHORUS VOICE: Thank Heaven Clarissa refused to marry him.

CHORUS VOICE: "Clarissa!" he cried. "Clarissa!” But she never came back. ${ }^{49}$

SALLY: Just passing through London. Heard Clarissa was giving a party! So I came -

CHORUS VOICE: Clarissa and Sally have always been friends, not acquaintances. ${ }^{51}$

CHORUS VOICE: In the old days, they would sit up all night talking. ${ }^{52}$

CHORUS VOICE: The wild, the daring, the romantic Sally! ${ }^{53}$

CHORUS VOICE: She would paint, she would write.

CHORUS VOICE: Everybody just adored her! $!^{54}$

CHORUS VOICE: Sally is still very attractive. ${ }^{56}$ 

cold in Clarissa. ${ }^{78}$

CHORUS VOICE: Once she picked a flower and kissed Clarissa on the lips.

CHORUS VOICE: Then the whole world turned upside down! ${ }^{57}$

CHORUS VOICE: What was this except being in love? ${ }^{58}$

CLARISSA DALLOWAY: Lady Bradshaw!

LADY BRADSHAW: We are shockingly late, dear Mrs Dalloway. ${ }^{59}$ (Sinking her voice) Sir William, my husband was called up on the telephone - a very sad case. A young man has killed himself. He had been in the army. ${ }^{60}$

CHORUS VOICE: Here's death in the middle of Clarissa's party.

CHORUS VOICE: Septimus is the young man's name.

CHORUS VOICE: He has just thrown himself from a window.

CHORUS VOICE: You mean, he took his own life?

CHORUS VOICE: Why did he do it? ${ }^{61}$

CLARISSA DALLOWAY (In a daze, as if a stranger to her own party) The thud, the rusty spikes - a suffocation of blackness. He has escaped! Are we not all prisoners? ${ }^{62}$

CHORUS VOICE: She feels like the young man who has killed himself.

CHORUS VOICE: She feels glad he has done it. ${ }^{63}$

CHORUS VOICE: She feels it is very, very dangerous to live even one day. ${ }^{64}$

CHORUS VOICE: This life, to be lived to the end - an awful fear. ${ }^{65}$

CLARISSA DALLOWAY: Death is defiance. Death is an attempt to communicate. ${ }^{66}$

CHORUS VOICE: There she is, forced to stand in her evening dress... when a young man, holding his treasure, sinks and disappears in this profound darkness. ${ }^{67}$

CLARISSA DALLOWAY: (Somehow it is her disaster. Odd, incredible, she has never been so happy) ${ }^{68}$ What an extraordinary night! ${ }^{69}$

\section{Act 2 - The notebook}

(The streets and parks of London. Bird sounds. The actors travel across the stage, walking, running, stopping and turning).

CLARISSA DALLOWAY: How fresh! How calm! ${ }^{70}$ I love walking in London. Really, it's better than walking in the country! ${ }^{71}$

CHORus voIcE: Peter was charming. But with Peter, everything had to be shared, everything gone into. It was intolerable! ${ }^{72}$

CHORUS VOICE: Sally's power was amazing: her gift, her personality. ${ }^{73}$ The purity, the integrity of their love! Only women can... ${ }^{74}$

PETER: That afternoon, when he came over, I had a revelation..$^{75}$ I knew Clarissa would marry Richard Dalloway. ${ }^{76}$ Her social instinct told her to. ${ }^{77}$ There was always something

RICHARD DALLOWAY: (Walking to his house in Westminster) ${ }^{79}$ Marrying Clarissa was a miracle. My own life is a miracle! ${ }^{80}$ She might have married Peter! ${ }^{81}$

SEPTIMUS: Leaves are alive, trees are alive! There is a god! ${ }^{82}$ (Stares madly at his wife) Love between man and woman is repulsive! ${ }^{83}$ Let me rest still! ${ }^{84}$ 
LUCREZIA: Why should I suffer? I can't stand it any longer! ${ }^{85}$ I was happy in Italy. I had a beautiful home. My sister lives there still. ${ }^{86}$ The English are so silent. ${ }^{87}$ The English are so serious. ${ }^{88}$

ELIZABETH DALLOWAY: The fresh air is so delicious! ${ }^{89}$ I wish I were alone in the country, with my father and the dogs. But they say I look like a lily ${ }^{90}$ and should go parties. ${ }^{91}$

SALLY: Clarissa has always been fond of society..$^{92}$ But why must she invite all the dull women in London! ${ }^{9_{3}}$ She is such a snob! ${ }^{94}$ But how extraordinary to see her again! I owe her an enormous amount. ${ }^{95}$

MISS KILMAN: It is the flesh, it is the flesh! God help me! ${ }^{96}$ Fool that you are, Clarissa Dalloway, lying on a sofa! ${ }^{97}$ You do nothing, believe nothing! ${ }^{98}$ You should be in a factory, behind a counter!

CLARISSA DALLOWAY: (Facing the audience) There is a dignity in people; a solitude; even between husband and wife a gulf. ${ }^{99}$ Here is one room; there another! That's the miracle, that's the mystery!100

\section{Act 3 - On the Edge of the World}

\section{(Distant sound of gunfire)}

SEPTIMUS: (Muttering, clasping his hands) They hunt in packs! They desert the fallen!101 They tear them to pieces! ${ }^{102}$

LUCREZIA: Why should I suffer? I have done nothing wrong? Why? ${ }^{103}$

CHORUS VOICE: Septimus, saying hard, cruel, wicked things to his wife! ${ }^{104}$

CHORUS VOICE: Septimus isn't Septimus any longer.

CHORUS VOICE: The rope is cut. Their marriage is over. ${ }^{105}$

SEPTIMUS: Evans! Are you behind this screen? For God's sake, don't come! I can't look upon the dead. ${ }^{106}$

CHORUS VOICE: Septimus, talking to that dead man Evans! His officer, and his friend! 107

CHORUS VoICE: They had to be together, share with each other, fight with each other, quarrel with each other. ${ }^{108}$

CHORUS VOICE: Evans was killed. The last shell missed Septimus. ${ }^{109}$

CHORUS VOICE: He watched his friend explode with indifference. ${ }^{110} \mathrm{He}$ could not feel. .11

SEPTIMUS: I have - I have committed a crime. ${ }^{112}$

LUCREZIA: You have done nothing wrong whatsoever. ${ }^{113}$ You've done your duty. ${ }^{114}$ You served with the greatest distinction. ${ }^{115}$

CHORUS VOICES: Friendship! War! Death! The whole show!116

SEPTIMUS: (Like a drowned sailor on a rock. Talking to himself again) ${ }^{111}$ Let me rest still. My bed is falling! I am falling! ${ }^{118}$

LUCREZIA: Dr Holmes has come to see you. Dr Holmes is such a kind man. ${ }^{119}$ You must let him help you. ${ }^{120}$

DR HOLMES: Headaches, fears, dreams - nerve symptoms, and nothing more! (Turning to Lucrezia) Give him another plate of porridge at breakfast! ${ }^{121}$

CHORUS VOICE: Dr Holmes is on him. Human nature is on him! ${ }^{122}$ 
CHORUS VOICE: Dr Holmes is a damned fool. But Dr Holmes has won..$^{123}$

SEPTIMUS: I know the meaning of the world. Now we will kill ourselves, won't we, Lucrezia? ${ }^{124}$

CHORUS VOICE: But she cannot understand him.

CHORUS VOICE: The whole world is clamouring "Kill yourself, kill yourself!" 225

CHORUS VOICE: He is quite alone now. He is deserted. Only the dead are with him. ${ }^{126}$

SEPTIMUS: Evans, Evans! $!^{127}$

DR HOLMES: (Enters the room again. In the most amiable way in the world) Now what's all this about? ${ }^{128}$

SEPTIMUS: Evans... behind this screen... with a message from the dead. Can't you hear? Do not cut down the trees! Go tell the Prime Minister! ${ }^{129}$

CHORUS VOICE: He is talking aloud to himself. ${ }^{130}$

CHORUS VOICE: He is all muddled up. ${ }^{131}$

CHORUS VOICE: He is straying on the edge of the world.

CHORUS VOICE: A drowned sailor on the shore of the world! ${ }^{132}$

SEPTIMUS (Turning to Dr Holmes): You brute! You brute! ${ }^{133}$

DR HOLMES: I'll give you something to sleep. (Looking ironically around the room) If you don't trust me, then go to Sir William in Harley Street! ${ }^{134}$

CHORUS VOICE: Sir William Bradshaw: the priest of science! ${ }^{135}$

CHORUS VOICE: The ghostly helper of nerve cases! $!^{136}$

CHORUS VOICE: Tact, sympathy, an understanding of the human soul! ${ }^{137}$

CHORUS VOICE: An endless stream of rich, afflicted patients! ${ }^{138}$

LADY BRADSHAW: A wall of gold mounting minute by minute! 139

SIR WILLIAM BRADSHAW: A complete physical and nervous breakdown. A case of extreme gravity! ${ }^{140}$ Has he threatened to kill himself? ${ }^{141}$

SEPTIMUS: I- I - ${ }^{142}$

SIR WILLIAM BRADSHAW (Kindly): Rest - a long rest in bed. We have a delightful home down in the country. ${ }^{143}$

CHORUS VOICE: Rest in bed; rest in solitude.

CHORUS VOICE: Rest without friends, without books, without messages.

CHORUS VOICE: Six month's rest! ${ }^{144}$

LADY BRADSHAW: Sir William shuts people up when they go under! ${ }^{145}$ He swoops, he devours his victims - the defenceless and the exhausted! ${ }^{146}$

SEPTIMUS: I am not afraid. ${ }^{147}$ Love, trees, there is no crime! No one can separate... (Flings himself violently down on to the railings) ${ }^{148}$

DR HOLMES AND SIT WILLIAM BRADSHAW: The coward! Why the devil did he do it? ${ }^{149}$

\section{Epilogue}

LUCREZIA: It is time. ${ }^{150}$ 


\section{Adapting Mrs Dalloway (1925) for a stage production}

A dramatist, of course, has no volumes to fill. He is forced to contract (...) The play

is poetry, we say, and the novel prose. ${ }^{156}$

4 Mrs Dalloway is a seamless flow of text, which "dislocates traditional form" (Henke 1981). This poses a major challenge for the common reader, and proves even more challenging for the common spectator, who is presented with a 1965-word reduction of Woolf's 64059-word narrative (3\%). The audience is given less than 20 minutes to identify the protagonists, make sense of their interactions, and reflect on their predicament. So the question is: "Can this be done?" and if so "How?" Judging by the warm reception at Teatro Civico (Vercelli, TILLIT 2018) and Cap Sciences (Bordeaux, European Researchers' Night 2018), the challenge can be met. Here is a brief description of the method used.

The novel was turned into a three-act play, with a "prologue" and a short "epilogue." The "acts" in Performing Mrs Dalloway are not just divisions that give formal structure to the play: they are the primary instruments of "inter-semiotic translation" (Jakobson 1959) or "resemiotisation" (O'Halloran et al. 2016) - the process whereby content is transferred from one medium to another across discourse types and literary genres. Acts allow the transition from letters printed on a page to movements made on a stage, from the continuum of experience - written and internalized - to lines, discrete and disconnected. Acts facilitate the shift from novel to drama, mental action to physical action, internal monologue to externalized thinking, reading to watching, describing to performing. "Acts" set ideas and emotions in motion (Lat. agere). They attest that speakers are performers (Goffman 1983), and that physical movement is instrumental in the social production and public display of meanings (Streeck 2009), however private or abstract these meanings might be.

In the present stage adaptation of Mrs Dalloway, each act bears a formal title. The title of Act 1 - "The Party" - is self-explanatory. Parties are the traditional locus of banter and chitchat, but parties do matter because "to communicate is our chief business; society and friendship are our chief delights" (Woolf [1925] 1984: 64). Voices are heard, comments made, views expressed, yet full conversational interaction between the guests is not staged. Clarissa "fulfills the post-war housewife paradigm" (D'Arcy, 2012:46): her manners are perfect and her parties intended as a "gift" to her husband a charming but mediocre politician, who has so far failed to become a Cabinet minister. But Clarissa is more than a politician's wife and her parties serve a wider, more generous purpose: they are "an offering for the sake of offering" (Woolf [1925] 2013: 114). The sudden revelation of Septimus's death gives unusual metaphysical depth to the occasion, and generates ambivalent feelings that Clarissa is careful to conceal from her guests. 
Death was defiance. Death was an attempt to communicate; people feeling the impossibility of reaching the centre which, mystically, evaded them; closeness drew apart; rapture faded; one was alone. There was an embrace in death (...) She had escaped. But that young man had killed himself. Somehow it was her disaster - her disgrace (...) Odd, incredible, she had never been so happy. (Woolf [1925] 2013: 172-73)

167 [1925] 2013: 83). The act is short but pivotal. It operates at a deeper level of
consciousness and functions as "a secret deposit of exquisite moments" (Mrs Dalloway [1925] 2013: 26). The characters' minds are suddenly made "transparent" and "accessible" (Edmondson 2012). This is in perfect conformity with Woolf's narrative technique: "characters (fundamentally) establish their selves through their thought patterns," and "disparate individuals" reveal their "interconnectedness" in the process (Flint 1992). Thoughts speak louder than actions, as it were, and the different flows of sensation and reflection eventually "merge into each other." The title of Act 3 is based on the tragic and deeply poetic image of Septimus "straying on the edge of the world", an "outcast (...) who lay, like a drowned sailor, on the shore of the world". The imagery is powerful, obsessive and quite distressing: "He was drowned, he used to say, and lying on a cliff with the gulls screaming over him. He would look over the edge of the sofa down into the sea" (Mrs Dalloway [1925] 2013: 86, 131).

The story is set in a single city (London) and unfolds on a single June day, in the aftermath of the Great War. There is no unity of action - although Clarissa's and Septimus's stories eventually blend - but there is definitely a unity of place and time that is resonant with classical tragedy. The play opens with Clarissa's party, whereas the novel postpones it to the very end:

The ladies were going upstairs already, said Lucy; the ladies were going up, one by one, Mrs. Dalloway walking last and almost always sending back some message to the kitchen (...) There, they were going upstairs (...) and now they would come faster and faster. (Mrs Dalloway [1925] 2013: 155)

In Woolf's novel, the protracted preparation phase percolates through 150 pages of uninterrupted narrative. In the stage adaptation, the preparation is briefly mentioned at the beginning. The Prologue mentions plans being made for a party (e.g. "I'm giving a party tonight! Remember!), and the opening lines of Act 1 simply confirm Clarissa's intention to host in style (e.g. "I will wear this dress tonight!"). The reasons for such simplification are strictly dramaturgical. The only way to engage the audience rapidly and efficiently is to use a familiar dramatic pattern: a formal social gathering has been organized; old friends are happily reunited, when a tragic incident occurs that changes the course of events. Death is an uninvited guest to the party. The spectator's curiosity is aroused: who is the young man who "threw himself from a window"? What was he trying to "escape" from? Why so much empathy on Clarissa's part? Who are these people? What are they after? In short, what is the purpose and significance of Clarissa's party? As Virginia Woolf (the essayist) wrote in The Common Reader ([1925] 1984: 51), we "have a right to demand (...) that what happens shall have an end in view."

Act 2 presents a succession of brief monologues. Each gives spectators an insight into a particular character's mind: the "private self" of a given individual is made "accessible" (Edmondson 2012). Identity, feelings, and relationships are displayed in "the public space" but reduced to something schematic and emblematic. A considerable amount of information has to be packed in just a few sentences. This is possible only because 
multiple inferences can be drawn from the little that is said. There is also a lot of walking in Act 2. As the characters physically travel across the stage, their minds metaphorically travel back and forth in time, between late middle age and youth. The result is "a kind of mingling of present and past (...) allowing for an intense experience of shared recall" (Boxal 2015). The protagonists in Woolf's novel are inveterate walkers. They are shown travelling on omnibuses, or roaming the streets and parks of London. Their "appropriation of the city" (Lanone 2009) through walks and journeys across the city is an integral part of the story.

Act 3 eventually solves the mystery of Septimus's despair. The script probes "into the mind of a trauma survivor" who suffers from "an inability to communicate his experience to others" (DeMeester 1998: 649). The fragmented lines are iconic of "the fragmentation of consciousness and the disorder and confusion that a victim experiences in the wake of a traumatic event" (650). Septimus is not helped by Holmes, the family doctor. Neither is he understood by Sir William Bradshaw, an obnoxious, money-grabbing "nerve" specialist in Harley Street. Both men stand for an "oppressive and insensitive" medical establishment (Bennet Smith 1995). Dr. Holmes minimizes the severity of Septimus's condition and prescribes "porridge." The "authoritarian" and "repressive rest cure" recommended by Sir William (Bennet Smith 1995) is strongly reminiscent of Virginia Woolf's own disastrous experience. Woolf clearly "wrote herself down"157 ([1925] 1984: 66) as she described Septimus's bipolar mood swings and violent interaction with doctors in Mrs Dalloway.

Yet, the "war trauma" (DeMeester 1998) and its corollary - deep "psychological and emotional damage" (Betha 2010) - do not account for all aspects of Septimus's "male hysteria" (Baldt 2006). His psychotic break, his "war-induced madness" (Lanone 2009), his "(inability) to overcome hallucinations" (Bennet Smith, 1995: 318), probably have deeper roots, one of which might be his repressed homosexual attachment to Evans, his commanding officer during the War: "There in the trenches (...) he developed manliness; he was promoted; he drew the attention, indeed the affection of his officer, Evans by name." (Mrs Dalloway [1925] 2013: 80). The "Evans / Septimus relationship" is one of "implied homosexuality." Like "the Clarissa / Sally relationship," it is "formative" (Krouse 2006) and euphoric in the first place: "They had to be together, share with each other, fight with each other (...) It was sublime. "158 The homosexual component in Clarissa and Sally's early friendship is even more explicit: "Then came the most exquisite moment of her life (...) Sally stopped; picked a flower; kissed her on the lips. The whole world might have turned upside down! (...) And she felt she had been given a present (....) - a diamond, something infinitely precious." ${ }^{159}$ But Septimus's desire for Evans does not translate into a kiss or some open physical embrace, which might account for Septimus being utterly inconsolable, unable to grieve and "differentiate between appropriate and inappropriate behaviour" (Baldt 2006).

Finally, the Epilogue - or Paradise Regained - achieves the "poetic union between Clarissa and Septimus" (Boxal 2015), which the performances in Vercelli and Bordeaux (2018) magnificently staged (see Figure 15). It stresses the "compassionate and optimistic" nature of the novel (Schowalter 2011), while highlighting Clarissa Dalloway's ambivalence about the party - a gripping mix of elation and depression, profoundness and superficiality, meaningfulness and meaninglessness.

In The Common Reader, Woolf sums up Montaigne's moral conception of beauty in the following terms: "Beauty is everywhere, and beauty is only tow fingers' breath from 
goodness." ([1925] 1984: 66). Septimus's last words in the play are based on the character's numerous references to "beauty" in the novel, as in "Beauty, the world seem to say. And as if to prove it (scientifically) wherever he looked, at the houses, at the railings, at the antelopes stretching over the palings, beauty sprang instantly (...) beauty, that was the truth now. Beauty was everywhere!" ([1925] 2013: 64).

\section{The Workshops: enhancing the interpretive potential of students}

Is it worthwhile? What is the point of it all? ${ }^{160}$

The workshop activities were designed to enhance the interpretive potential of students through creativity and embodiment. This is by no means common in French educational practice: complex literary texts are typically read at home then submitted to close thematic and stylistic analysis in the classroom. Formal discussions are held under the strict guidance of teachers, and literary theory is generally invoked to establish "critical distance." Students eventually produce their own pieces of analysis, in the form of "close reading exercises" (Fr. commentaire de texte) or "essays" (Fr. dissertation), based on conventional rhetorical patterns. Although creative writing exercises (Fr. sujets d'invention) are now also used to assess literary skills in secondary education, constraining rules must be followed and formal writing remains the dominant expressive medium.

176 From the outset, Performing Mrs Dalloway was conceived as an alternative way of experiencing a complex piece of literary fiction. Although the experience was meant to be pleasurable and memorable, the "performative" approach was presented to participants as "serious stuff" - not a recreational fantasy. Students were told that the ultimate aim of the workshop sessions was the production of tangible and meaningful acts of understanding. They were expected to engage physically in their work, using vocal and kinetic resources to enact - not just describe - characters, relationships, moods, situations, concepts, or narrative perspectives. Thus, teaching and learning would become genuine "art forms" (Piazzoli 2018), with a marked aesthetic component.

177 The conversion of learning space into performance space means that embodiment becomes a vehicle for interpretation (Lindgren \& Johnson-Glenberg 2013), and movement a medium for choreographing thought (Lapaire 2016, 2017). New connections are set up between mental activity and kinetic activity; sense-making and sensory-motor experience. Participants are led to ask themselves new types of questions, which are both practical - "What should I be doing now that I am being asked to stand and perform my understanding of a character or a situation in this novel?" - and theoretical: "What are the issues - pragmatic, aesthetic, poetic, dramatic, etc. - which are raised in this particular scene that I am being asked to "act out" with my body?

All forms of instruction and learning, irrespective of the subject taught or methods applied, require interpretive skills from students and instructors. Texts, equations, diagrams, pictures, and recordings all "signify" in some way or other: meanings need to be construed, connections established, and inferences made. Most of the teaching material used in literature classes is made up of written texts that are offered for interpretation. The ultimate purpose of the interpretive process is a higher form of understanding conducive to personal appreciation and enjoyment. What goes on in a literature class may thus be viewed as a form of exegesis - the critical interpretation of 
(complex) texts. But "interpretation" should not be viewed as a mental and scriptural process only. Other strategies exist that teachers and learners may apply to make sense of literary works. The claim made in this paper is that the interpretive potential of students tends to be underused in standard classroom practice because interpretation is not conceived as a three-dimensional process:

179 - cognitive: interpretation is about understanding a piece, i.e. behaving like a scholar whose job is to decide on the meaning or significance of something;

180 - performative: interpretation is about playing or acting out a piece, i.e. behaving like an actor or musician performing a role or a score;

181 - translational: interpretation is about switching from one semiotic system to another, i.e. working like a translator or "interpreter" who has the capacity to choose another medium of expression so as to make some meaning accessible to people who might otherwise not understand (much).

182 Adapting a novel to the stage does indeed require interpretive skills in all three senses cognitive, translational and performative. Participants must prove their ability to deconstruct, repackage and deliver meaning outside their usual reading and learning spaces.

In the Spring of 2018, two groups of students were invited to engage in the performance of Mrs Dalloway and explore their own interpretive potential: 40 juniors aged 16-18 at Lycée Bossuet (Gers) (Fr. 1ere L), and 38 M.A. students aged 22-28 (30 enrolled in the "Choreography of Speech" seminar [English Studies], and 8 in the "Performing English" module [Theatre Studies], Université Bordeaux Montaigne [UBM]). None had ever read Mrs Dalloway before, although some graduate students had heard about Virginia Woolf. They vaguely knew about the modernity of her style ("stream of consciousness" was mentioned a few times in preliminary discussions) and her depression.

\section{Working with Oliver Borowski -'Raising the Dead' and 'The Last Supper'}

Oliver Borowski is a professional actor. He was born in South Africa to German parents, studied drama in Berlin, and founded the Theatre Shake Company in Bordeaux in 2009 with Carole Deborde. He was invited to give workshops by the English Department, as a guest artist (March-April 2018). 3 sessions, totaling 8 hours, were arranged with the 38 M.A. students enrolled in the Choreography of Speech seminar. ${ }^{161}$

In his general introduction to the workshops, Oliver Borowski stressed the importance of "looking", "listening," and "risk-taking" in acting. He was particularly attentive to stage presence, mutual awareness, and connection with the audience. To achieve greater clarity, cohesion and postural control in the tableaux, he asked participants to imagine that some invisible "camera" was taking shots from various angles. The trick worked beyond expectation and soon led to cleaner and sharper movements. 
Figure 2

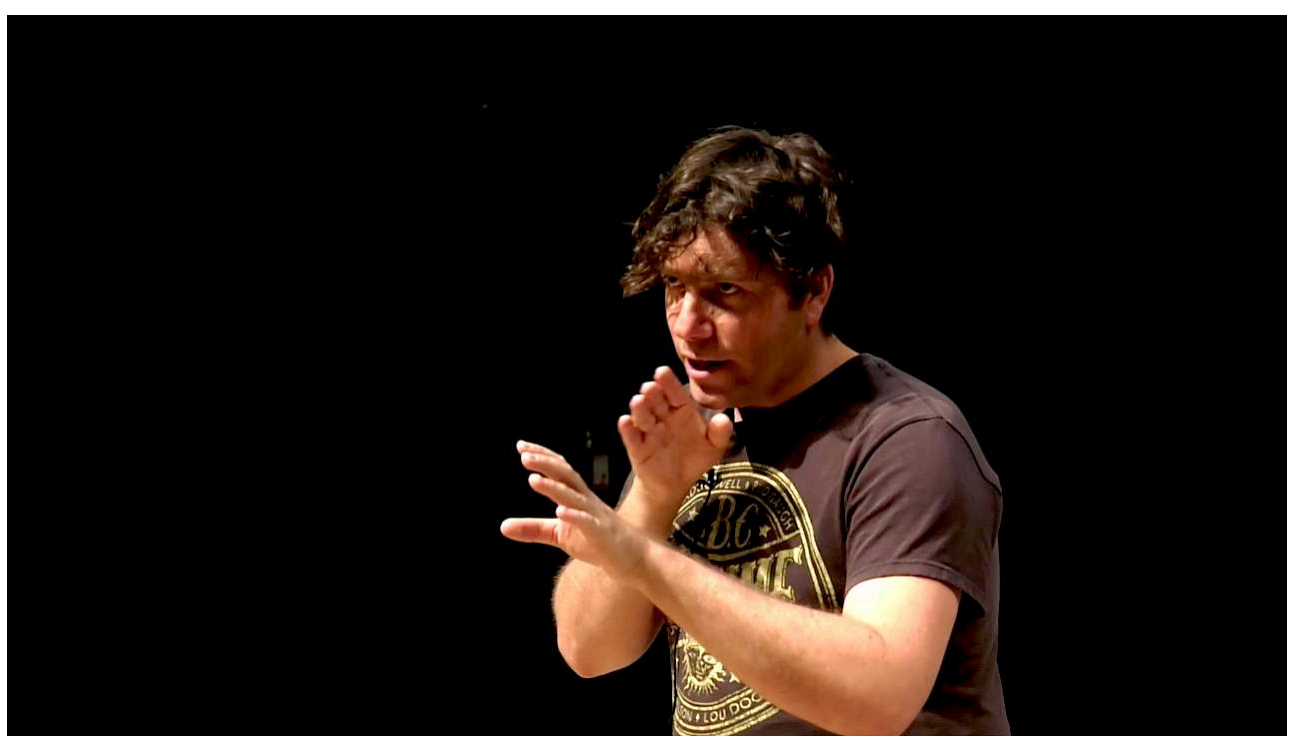

Oliver Borowski: giving instructions

Articulation and voice projection were an issue with most students, so urgent remedial work was carried out straightaway. Individual nouns (e.g. "world," "Clarissa"), verbs (e.g. "stray," "explode") or adjectives ("cruel," "charming") were metaphorically construed as "javelins" to be "thrown." Participants used the totality of the performance space to stage spectacular "running throws." They gathered speed then stopped abruptly to release their javelins in the air, in perfect synchrony with the syllable bearing the main stress (e.g. "violent," "charming," "intolerable"). The option was given to prolong certain vowel sounds during the flight of the javelins (e.g. "calm"), until the imaginary projectiles hit the ground. The unstressed initial or final syllables in longer words were synchronized with the preparation and retraction phases, as in "e [preparation] nor [strike / throw and freeze] - mous [retraction]". The combination of "javelin throws" with more conventional exercises had a spectacular effect on most participants: it raised their awareness of physical engagement in speech production, removed inhibition and self-consciousness, but did not fix long-standing pronunciation or intonation problems. 
Figure 3

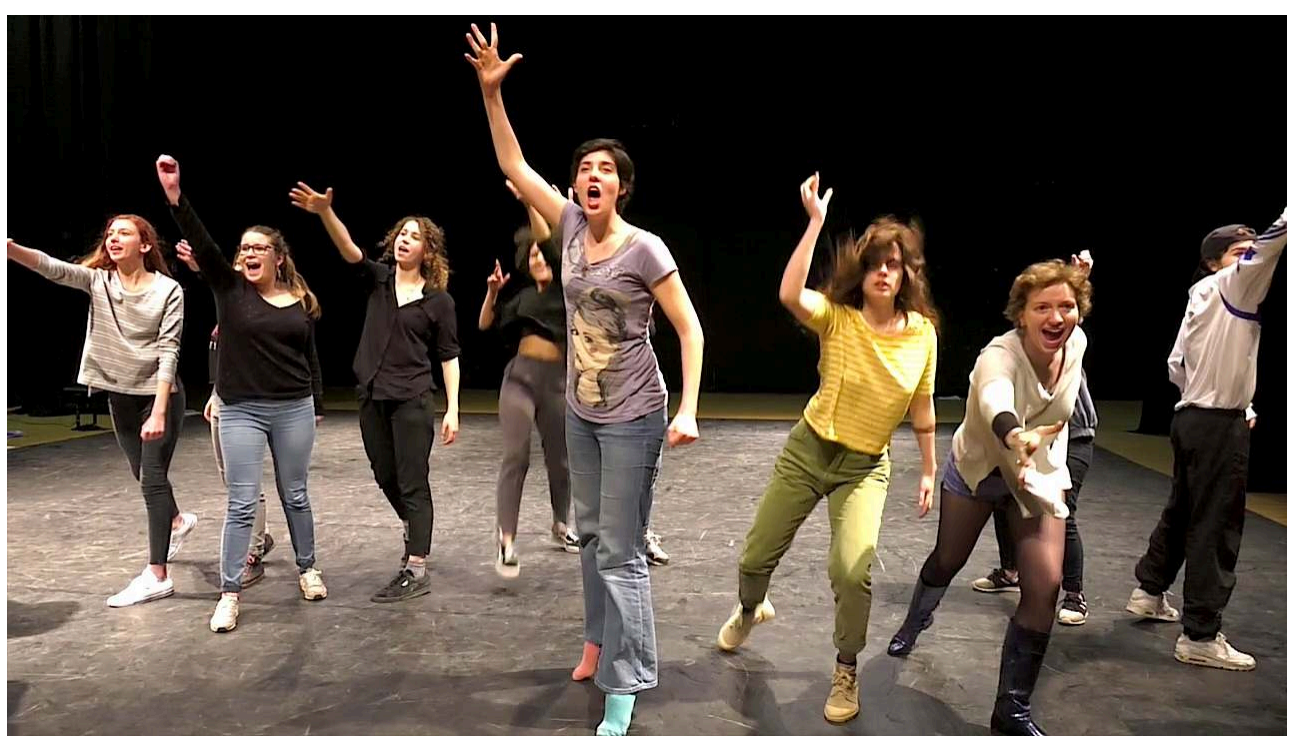

Gesture and voice projection: invisible "javelins" thrown

Participants were now ready to explore ways of performing Mrs Dalloway. Both practical and aesthetic considerations guided Oliver Borowski's dramaturgy. He chose to begin the performance with an evocation of "the War," which pervades Virgina Woolf's entire novel. Although the story is set in 1923 and much has changed since "the armistice" ("Those five years-1918 to 1923-had been [...] somehow very important. People looked different. Newspapers seemed different") the war is not quite "over" yet. There is the raving, war-damaged figure of Septimus, who suffers from "shell shock", mourns Evans ("his officer") and is haunted by memories of "mud," bursting shells and "wounds." But there are also the war "widows" and "orphans", who are "waiting to see the Queen go past." There is "Mrs Foxcroft at the Embassy," whose "nice boy was killed," and there is the inconsolable Lady Bexborough, whose "favourite" son John died too. Not to mention Miss Kilman, who was unfairly "dismissed" from "Miss Dolby's school" because "her family was of German origin." In actual fact, "every one has friends who were killed in the War," and no mind can be expected to be at peace yet with the horror and injustice of war. The "hot sun" and the "colours," "the whirling young men, and laughing girls (...) taking their absurd woolly dogs for a run" should not deceive anyone: the exhilarating explosion of life in post-war London is inseparable from the battlefield explosions of "the War." Life in the aftermath of WWI is an emanation from the dead, something that "arises" or "flows out" (Lat. e-manare) from a mixture of war blood and mud. This, at least, is what Oliver Borowski set out to show as he made suggestions for staging the Prologue.

The students were split into four separate groups and asked to design and coordinate simple movement sequences - martial, expressive but silent. The "squads" or "contingents" walked onto the stage in close succession, drilling, marching, engaging in battle, and eventually dropping to the ground: no survivors, just scattered bodies, some lying on top of each other. After a short moment, the performers started to "rise from the dead," expressionless, some alone, others in twos or threes, in random succession, each delivering some cryptic "message" from below (very much like Septimus) - typically a word or sentence: "The flowers" "Remember" "The ebb and flow 
of things" "Westminster" "I must tell the whole world," etc. The visual impact of so many "dead" bodies coming to life again, with dazed looks on their faces, was extremely powerful, while the collage technique created a deep sense of mystery.

\section{Figure 4}

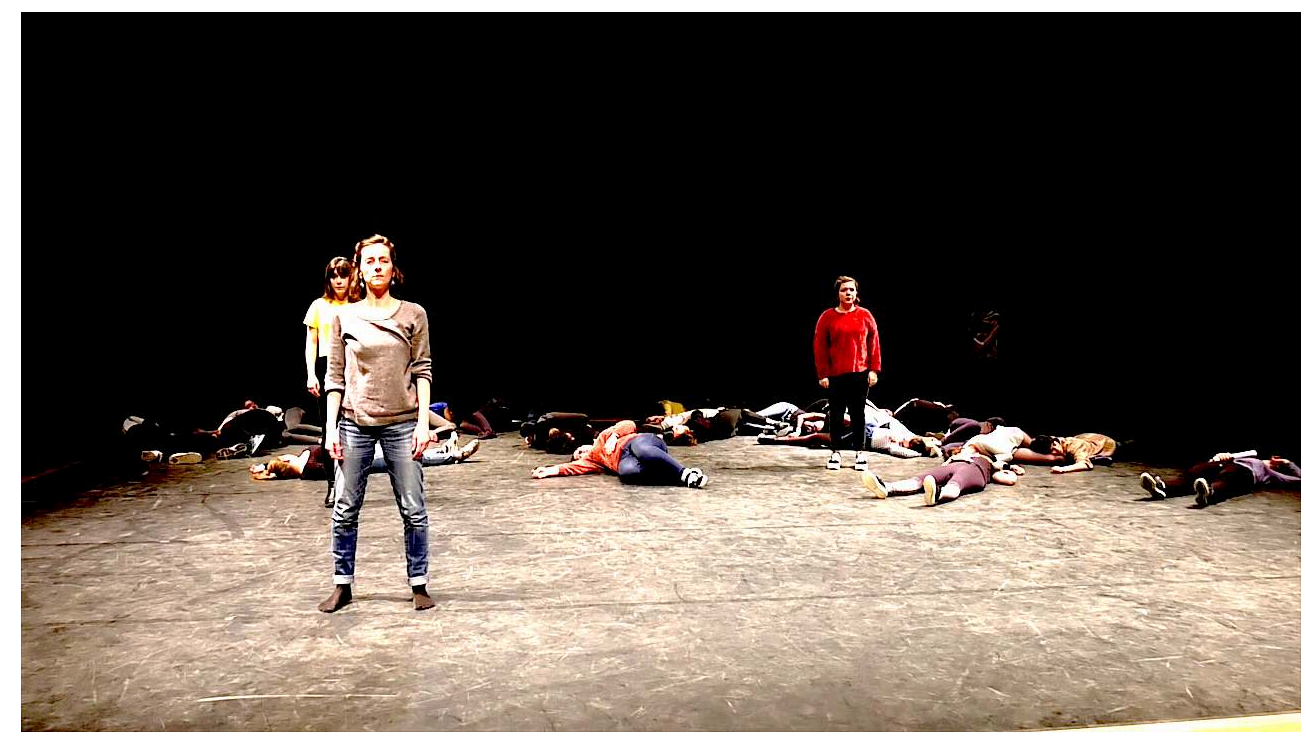

Rising from the Dead

Oliver Borowski's next decision was to cut out the dialogues and interior monologues, which few students would have been able to handle properly for lack of experience in the performing arts. He kept to the short and relatively simple lines written for the chorus. No role distribution would be needed, he explained, since the "voices" were anonymous and in sufficient number for everyone to "pick one and have a go." He felt that the simple, self-contained messages spoken by members of the chorus would be much easier to deliver, and that there was enough material to "advance the plot." So he asked participants to gather into small "chorus cells," and choreograph scenes or dynamic tableaux in which "action" (someone says or does something on the stage) and "reaction" (the others responds to the "doing") would systematically work together. 


\section{Figure 5}

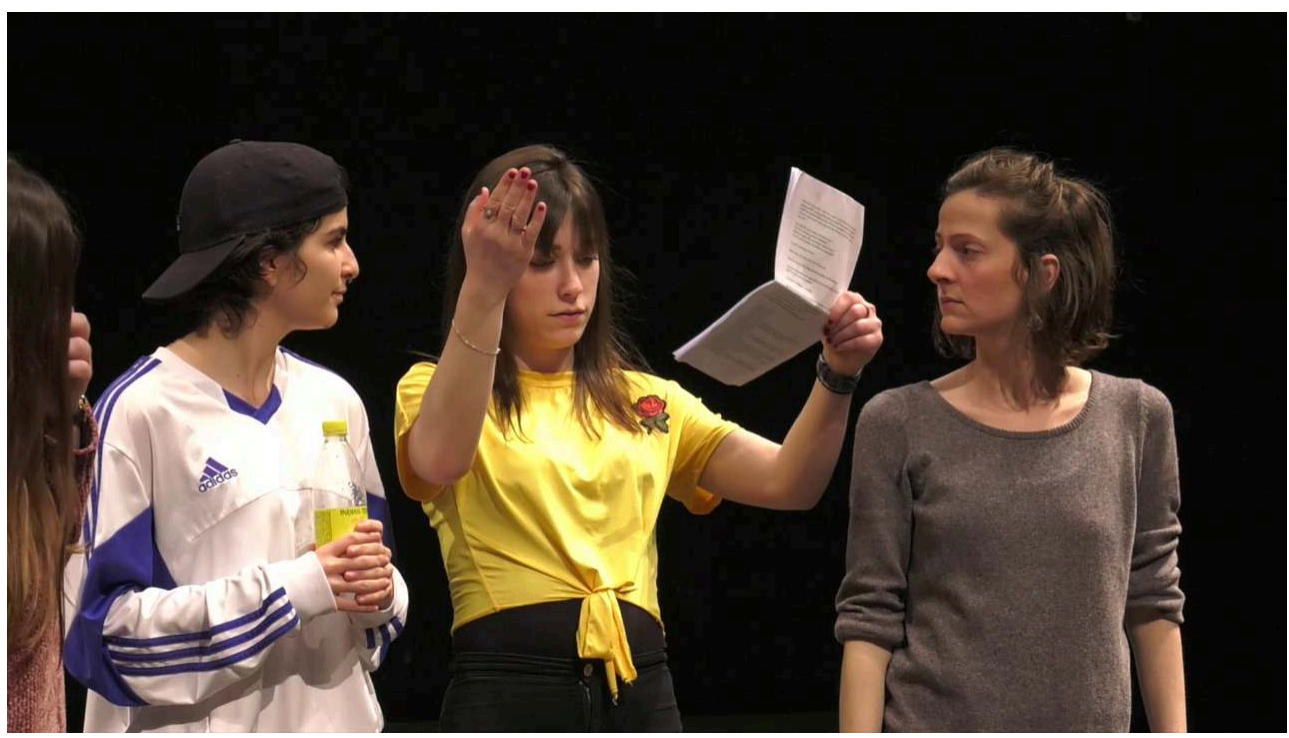

Exploring options in small groups

\section{Figure 6}

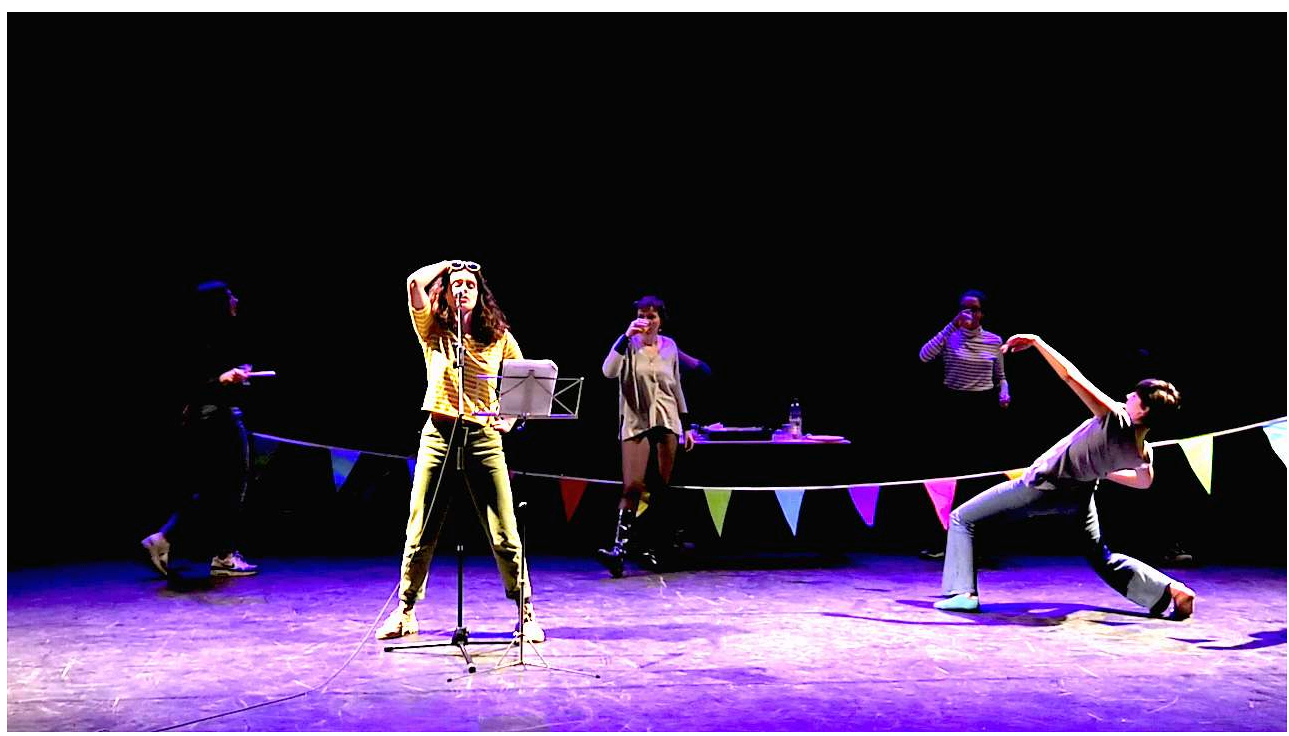

Small performing an anachronistic version of Act 1 - "The party"

190 A "grand finale" was staged on the last day, which summed up the whole creative process. The entire group performed the Prologue one last time under the code name 'Raising the Dead'. Then the "chorus cells" were activated, and the small groups performed in a strict chronological sequence, while the others sat and watched. Finally, everyone was called back onto the stage for a collective improvisation scene inspired by the "Last Supper." Oliver Borowski asked participants to visualize Michelangelo's Ultima Cena (1495-98) and use its pattern to position themselves in space. As he read the Epilogue ("It is time...") the performers responded kinetically to the meaning in "matching" or "mismatching" modes. The shifting physical postures, the dynamic bodily movements and the changing facial expressions would either support or contradict the meanings. Participants would briefly engage in body action then freeze. 
As expected, the non-iconic, non-redundant bodily actions (e.g. wincing, cringing, crawling or pulling faces to the sound of "The young are beautiful") proved the most powerful.

Figure 7

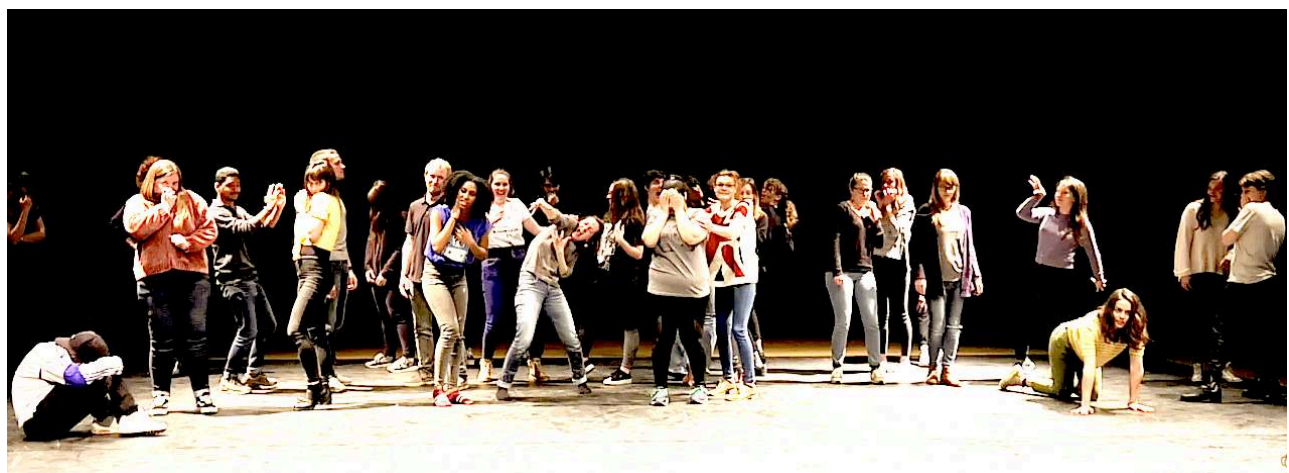

Epilogue: the horror and ugliness of "Beauty is everywhere"

Expressive mismatch between posture \& meaning

\section{Working with Melissa Blanc - 'Shoaling together'}

191 Melissa Blanc is a professional French dancer and choreographer. She received formal artistic training at CRR Poitiers before moving to Bordeaux. In 2014 she was invited to perform in Valérie Rivière's production "Toutes les filles devraient avoir un poème" (Compagnie Paul Les Oiseaux). She choreographed the activities for the 2 workshops that were held at Lycée Bossuet (Gers) in May 2018. ${ }^{162}$ Each session lasted 3 hours. The 40 juniors (aged 16-18) had read the script before the session and were asked to memorize a few chorus lines (in each act), to be delivered during the exercises and eventually pieced together as part of the final group performance.

As a dancer, Melissa Blanc was instantly struck by the myriad scenes of "pacing," "walking," "strolling," “running," “moving", “crossing," "turning," "shuffling," "leaping," "springing," and "jumping," which are reported in the novel, as in "she moved; she crossed; he followed her"; "the greenness (...), he thought, strolling across the grass"; "people gazed round and shuffled past the tomb of the Unknown Warrior"; "they must get away from people, he said (jumping up)." Her attention was also caught by the constant shifts between isolated individuals, who stand out in the novel because they experience some special sensation or inner revelation, and human aggregates: dyads, triads or groups of people who socially engage with each other and must synchronize their behaviour accordingly. The small groups are made up of master and servant; teacher and pupil; doctor and patient; husband and wife. Larger groups include children playing in the parks; friends and party guests talking to each other; anonymous London crowds moving around the city; the police, Navy and Army acting together.

Melissa Blanc set herself the task of integrating all these features into a single choreographic frame uniting motion events (e.g. "walking," "crossing," "turning") and shifting positions in the narrative (alone and pensive or in interaction with others). She drew her inspiration from the work and reflections of Hervé Dianas (2012a, 2012b), a French choreographer who has developed a group movement technique known as vol 
dansé - literally "a bird flight dance." Dianas (2012b) defines vol dansé as a form of "group perambulation" ( $\mathrm{Fr}$. déambulation collective) inspired by the swirling and soaring unison of bird flocks: "Of course we are not flying in the air, we are just walking together." In vol dansé configurations, just as in nature's bird flocks, individuals are united by a strong sense of "connected intelligence." They must constantly "stay in touch with each other" to engage in a "collective experience" of space and movement (Dianas 2012b). They trace straight, curved or diagonal lines, and most significantly overcome situations of disruption or "turbulence" by restoring spatial, rythmic and kinetic cohesion with "the other people they are flying with."

Melissa Blanc choreographed a group movement for Mrs Dalloway based on those very principles. In her presentation to the students, she extended the analogy to include other synchronized formations. Packs of wolves or hyenas (since Septimus himself thinks of "human beings" as creatures that "scour the desert" and "hunt in packs"), swarms of wasps or insects were invoked to develop the aggressive stances associated with the war (in the Prelude and in Act 3). But the preferred image was that of fish shoaling together and swimming in schools, since they really "move together as if choreographed" (Herbert-Reed 2016). The analogy was extremely useful to encourage greater swiftness and fluidity of movement, to discover attraction and repulsion rules, to maintain a constant state of readiness: moving together in synchrony; propelling oneself forward; responding to a neighbour's changed position and aligning with their new orientation; accelerating and slowing down.

Figure 8

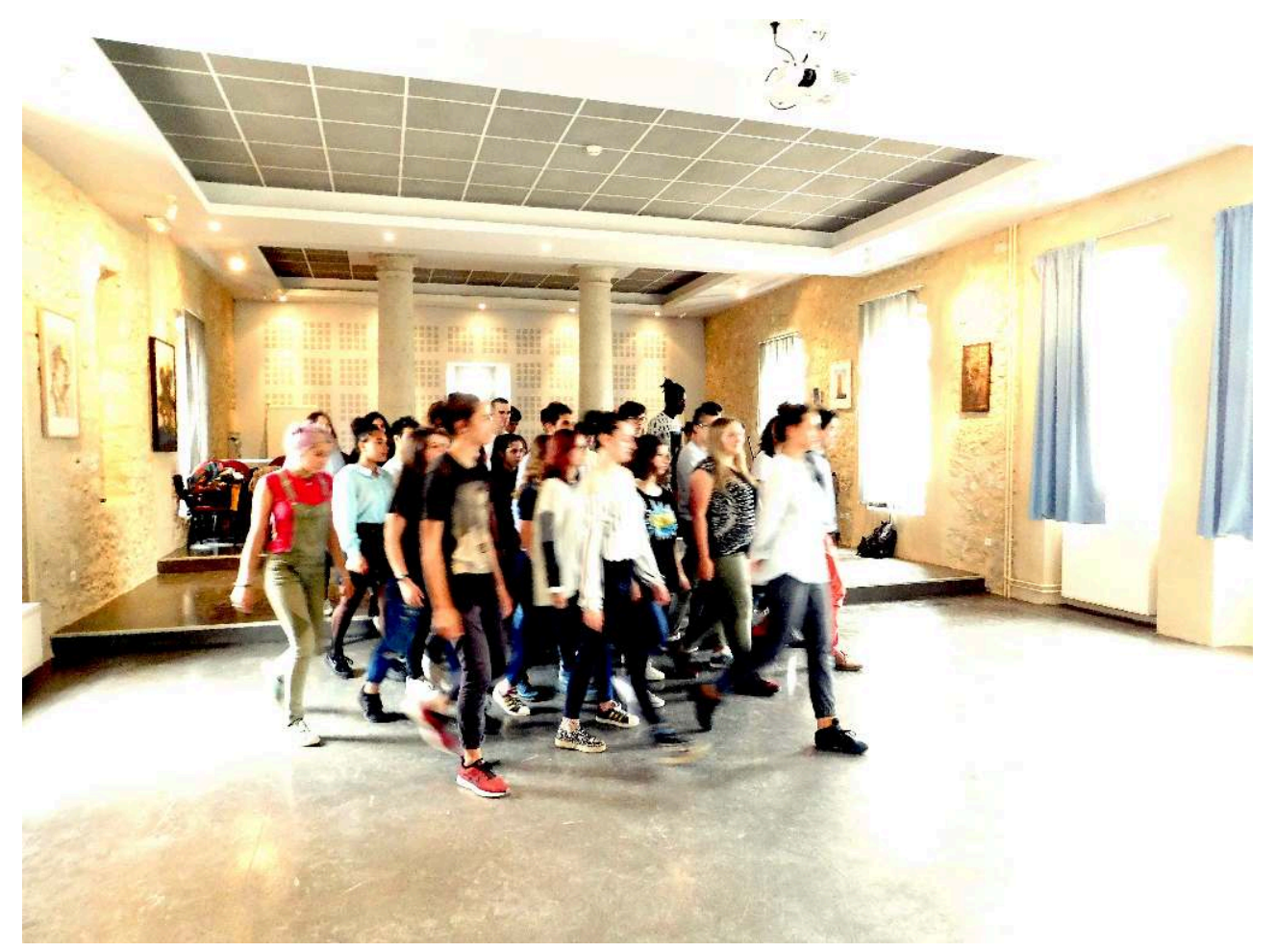

The synchonized formation is first led by Melissa 


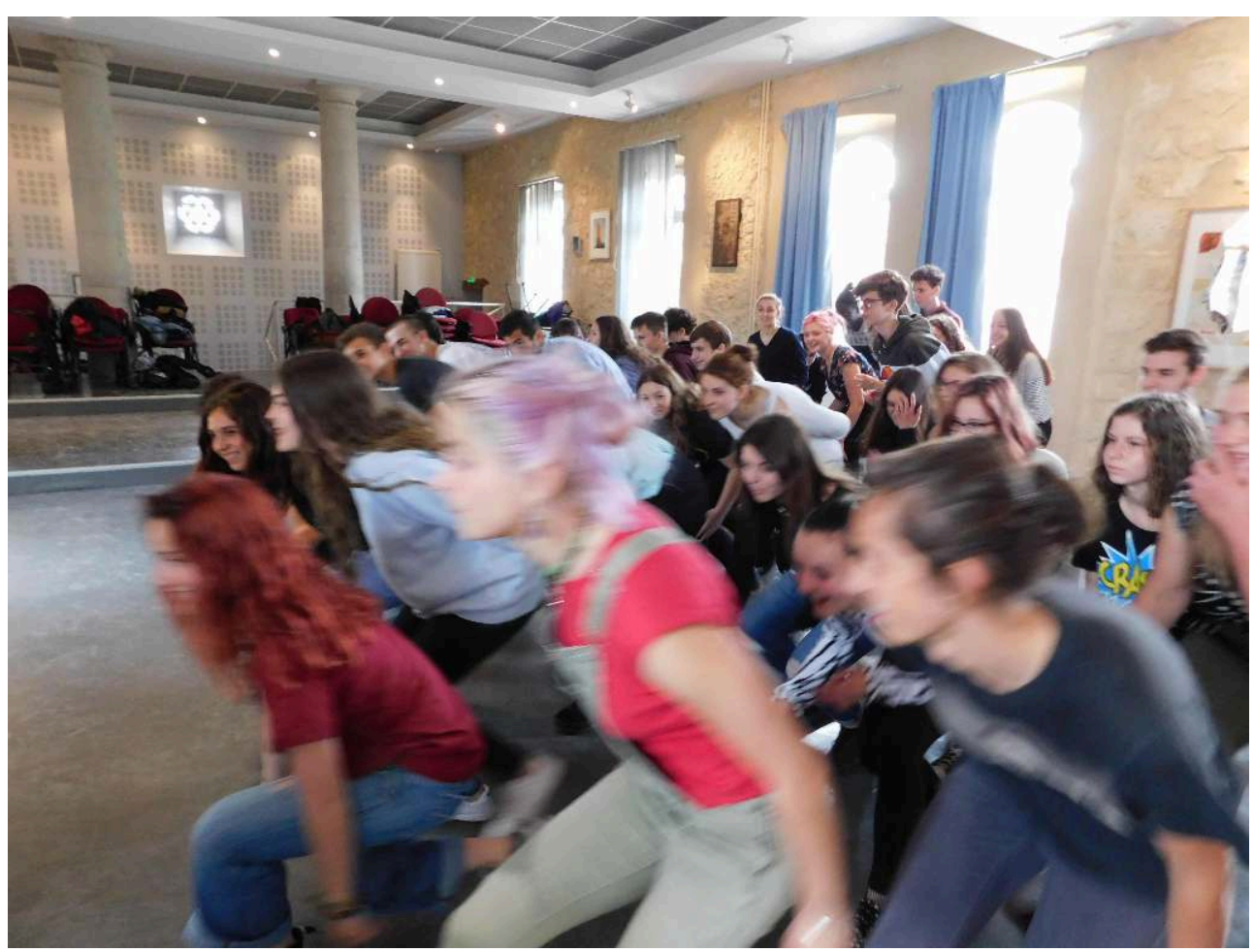

"Vol dansé en intérieur"

Flock forms and flies together in formation (indoors)

The students were instructed to vary the patterns of collective motion while remaining in aggregation all the time (which proved challenging at times). They travelled across the room together. The performers would engage in vol dansé and at some point, individuals or small groups would detach themselves from the rest of the group to deliver their "message to the world," in a clear allusion to Septimus Warren Smith's tendency to make dramatic pronouncements about life and the universe. Since many students experienced difficulty articulating their lines properly, Melissa Blanc introduced a number of exercises designed to give "depth and substance" to their words, based on "body-mind centering" techniques. Students would travel from one end of the room to the other, staggering, and as they clung to the wall opposite (or even collapsed), they would expel the air from their lungs and lamentably exhale what they had to say. This produced stunning results. 
Figure 10

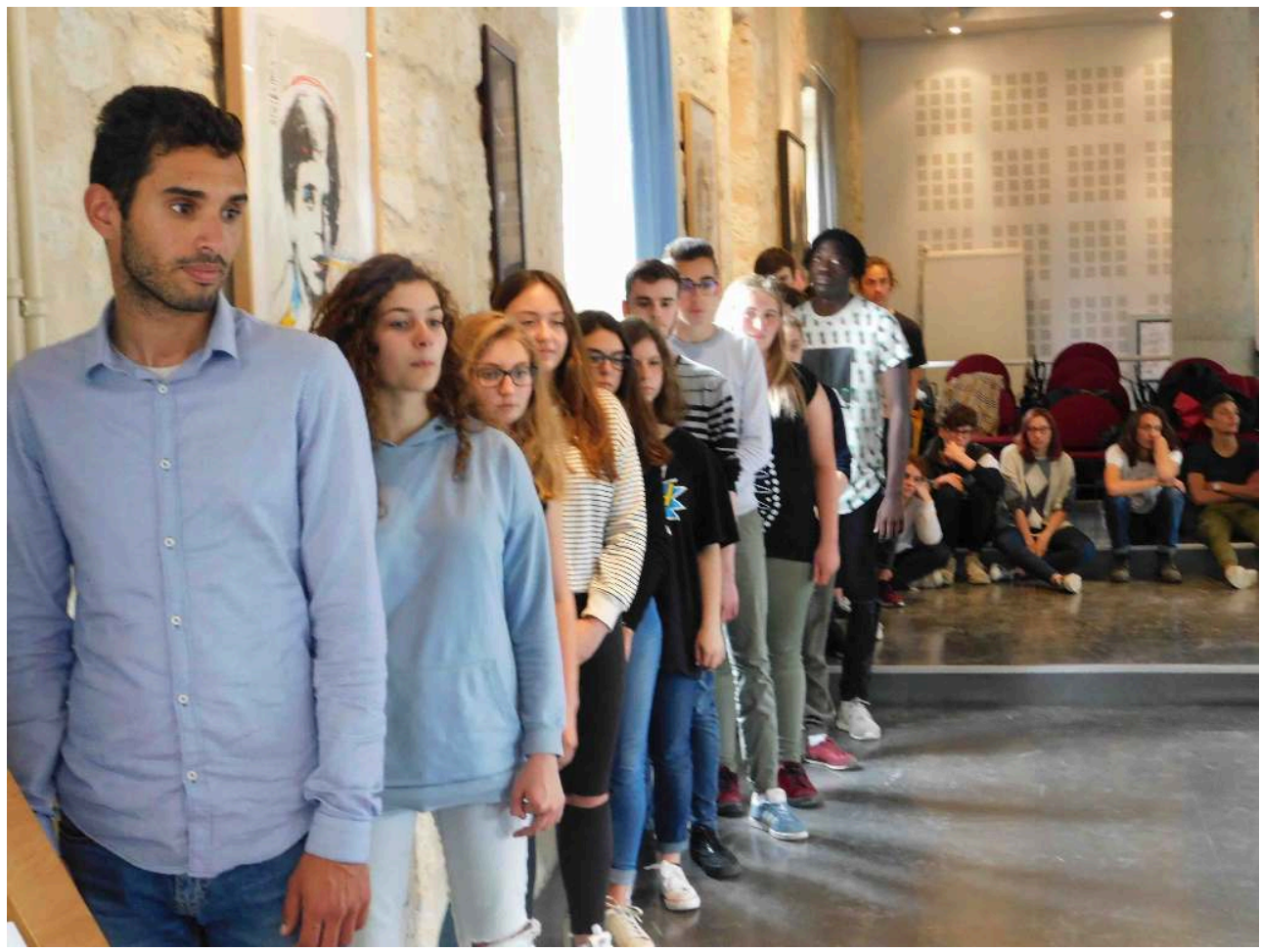

Getting ready for the pronunciation exercises

In vol dansé all members of the group tacitly agree to move together in the same direction. The dynamic structure is in principle egalitarian and no "leaders" are expected to take over. But this can only work if the individuals actually flock or shoal together (in the animal world) or have received sufficient professional training (in the dance world). The High school students were clearly beginners, so Mélissa Blanc appointed "guides" operating in turns, deciding on direction, speed and manner of motion. 


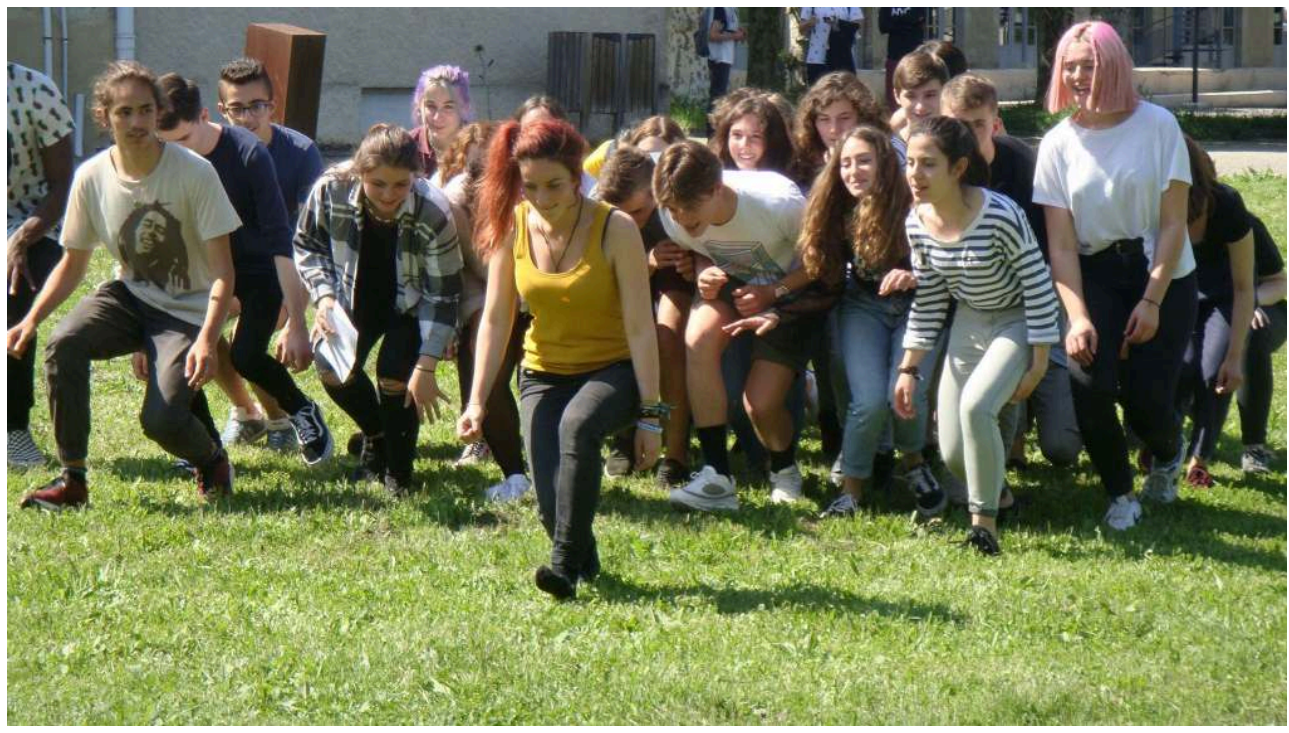

"Vol dansé en extérieur"

Group moves in unison, following a leader (outdoors)

\section{Working with Claire, Clémence \& Chloé - 'Blood on their hands'}

Claire Gabriel, Clémence Biensan and Chloé Dagois are MA students in Drama at Université Bordeaux Montaigne. Claire is a dance major, while Clémence and Chloé both hold degrees in Theatre Studies. All three took an active part in Oliver Borowski's workshops in March and April 2018. They had no trouble mixing with the 30 students from the "Choreography of Speech" module, sharing their stage experience with them and offering whatever technical support was needed. In return for their artistic engagement, Claire, Clémence and Chloé (and 5 other members of their group) were given intensive training in English, so the benefits were mutual. Eventually, they felt confident enough to perform in a language other than their native French - something they had never done before. The atmosphere was studious, collaborative and goodspirited.

The three student directors agreed to re-stage Performing Mrs Dalloway in May 2018 for the TILLIT festival, organized by Pr. Marco Pustianaz at Università del Piemonte Orientale, Vercelli (Teatro in Lingua, Lingua in Teatro 2018, see next section). They codirected a new production with 11 M.A. students from the English Studies program, who volunteered to take part in the event and were awarded a travel grant from the Faculty of Modern Languages. All those involved in the TILLIT 2018 project had explored the script with Oliver Borowski earlier on. The team agreed to build on Oliver's ideas but rightly insisted on making their own creative contribution to the new enhanced performance.

The reference to the War, which opens the Prologue, was preserved but the battle scene simplified. There was no confrontation between the belligerents: all the actors travelled together across the stage as a single "pack" or "hound," in reference to Septimus Warren Smith's words ("They hunt in packs. Their packs scour the desert and vanish screaming into the wilderness. They desert the fallen)." The sound of distant gunfire was heard, the actors lost their balance and reeled back, dropping dead, only to 
rise up again shortly after, one after the other, and deliver their lines. The performers were dressed informally, except for Clarissa Dalloway (Jeni Peake) - already "standing in her evening dress" - and Septimus (Edward Hamp), young, manly and handsome in his two-piece suit, but lost and alone. The layer of women's make-up on his face suggested a deep and mysterious connection with Clarissa. Interestingly, the two actors - both of them native English-speakers - chose to mark the commonalities between Clarissa and Septimus by de-emphasizing the elements that all too clearly united them: past homosexual attachments (between Clarissa and Sally, Septimus and Evans); a general feeling of isolation and disconnectedness. The lines in the script were left to speak for themselves (e.g. "Once she picked a flower and kissed Clarissa on the lips / Then the whole world turned upside down / What was that, except being in love?"), and sudden "revelations" were delivered in a detached, matter-of-fact way (e.g. "Leaves are alive, trees are alive! There is a god! / Love between a man and a woman is repulsive!"). Meanwhile, Claire Gabriel used silent dance movements to weave "kinetic threads" into the texture of the performance, linking characters and scenes together, part-mistress of ceremonies, part-guardian angel.

Figure 12

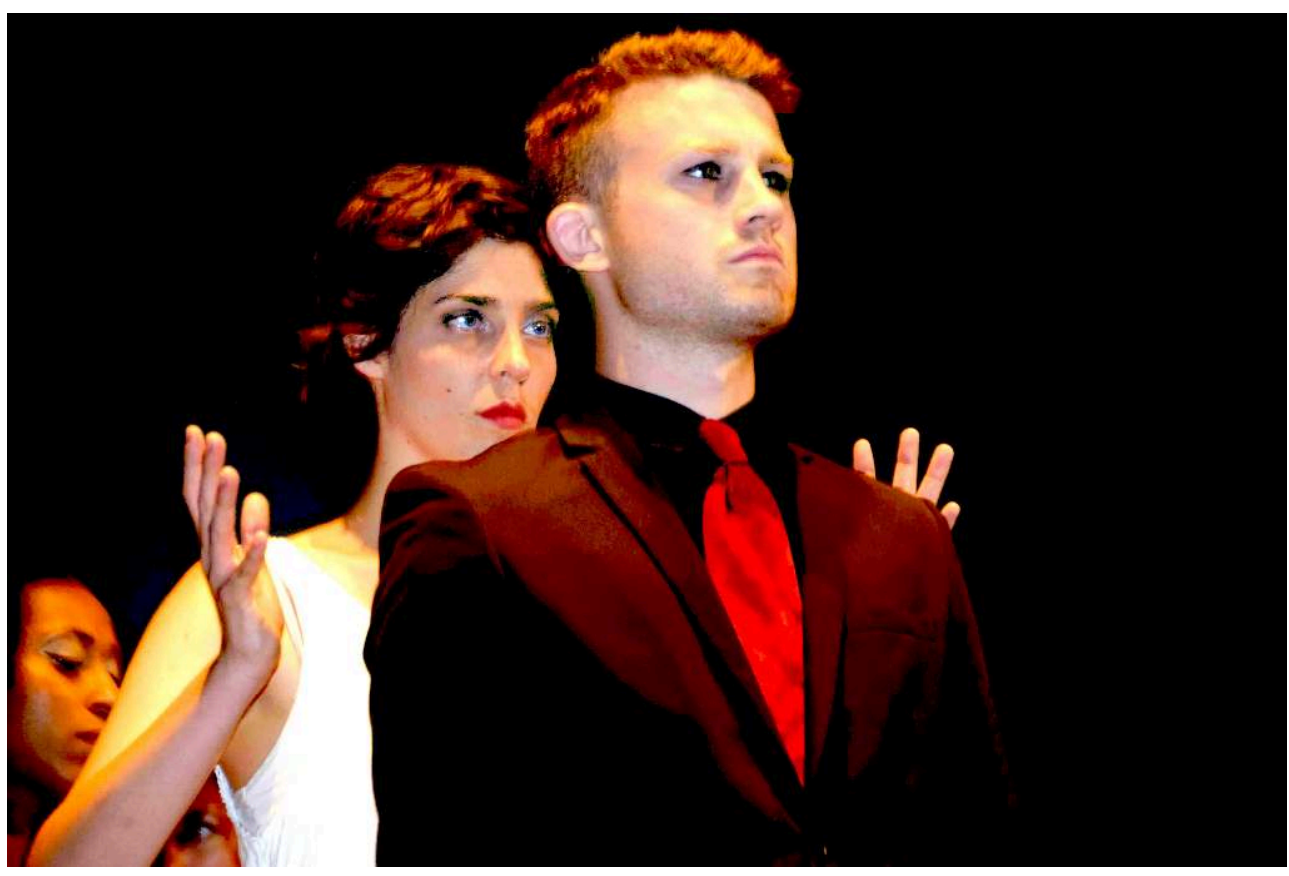

Claire's silent kinetic presence behind Septimus

Oliver Borowski's idea of splitting the "chorus" into "cells" was further refined. Members of the "chorus" acted both as insiders and outsiders. Small, temporary human aggregates would spontaneously form and dissolve that looked like clusters of guests making random social contact at Clarissa's party. But instead of engaging in conversational interaction, as normal characters might be expected to do in a regular play, members of the chorus would produce short, fragmented, plot-advancing narratives, unless they chose to elaborate on some key action or statement by a protagonist. This is what so-called choral characters typically do “(...) who largely stand apart from the action and by their comments provide the audience with a special perspective through which to view characters and events" (Abrams, 1971: 24). In 
Performing Mrs Dalloway, the perspective was shown to be constantly shifting, with different groups of choral characters positioning themselves differently in space, verbally and kinetically expressing the multiple angles, stances and perspectives expressed in Woolf's original novel (e.g. seeing Clarissa successively through the eyes of Peter, Richard, Sally and Miss Kilman; looking at Elizabeth from her father's and tutor's perspectives).

201 The walks in Act 2 were performed at different speeds and in different styles, as the actors criss-crossed the stage and soliloquized. The streets of Westminster and the Royal Parks of London were used as loci for self-disclosure. The protagonists had to find a way of stepping out, drawing attention to themselves, one after the other, before blending into the crowd again. A contrast was set up between the faceless people "out there" and individual characters; the continuous flow of physical movement and the sudden, unpredictable bursts of insight; the blandness of the crowd and the deep revelations about the self.

\section{Figure 13}

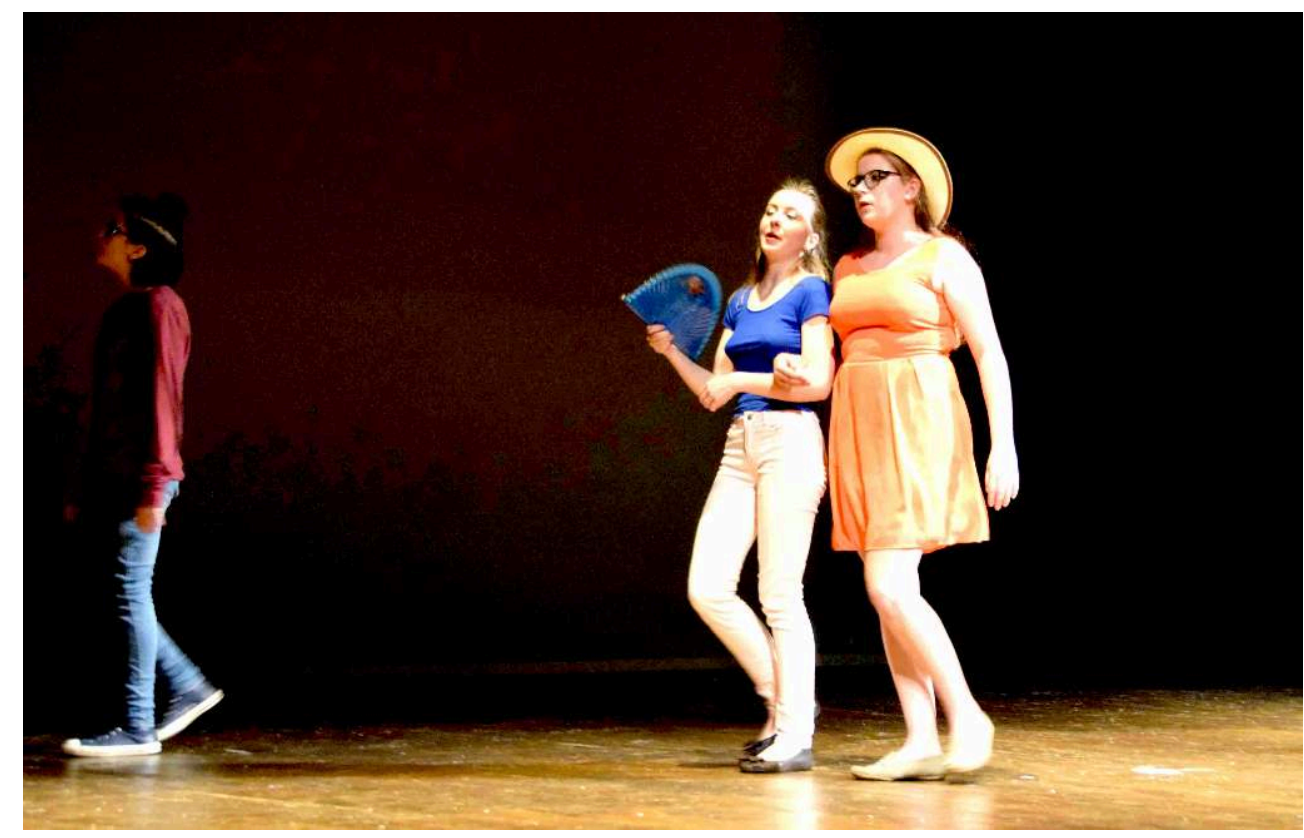

Act 2: Taking a stroll through Westminster and the Royal Parks

202 At the end of Act 3 ("On the Edge of the World"), Clarissa's "offering" (the party) symbolically acquired a sacrificial quality, akin to Holy "communion" in the Catholic ritual (Henke 1981: 126). Acting as "celebrant of a pagan Mass," Clarissa served wine to her guests, which turned into Septimus's blood, through a form of "transubstantiation." The wine was poured by the party guests into Septimus's hands. 
Figure 14

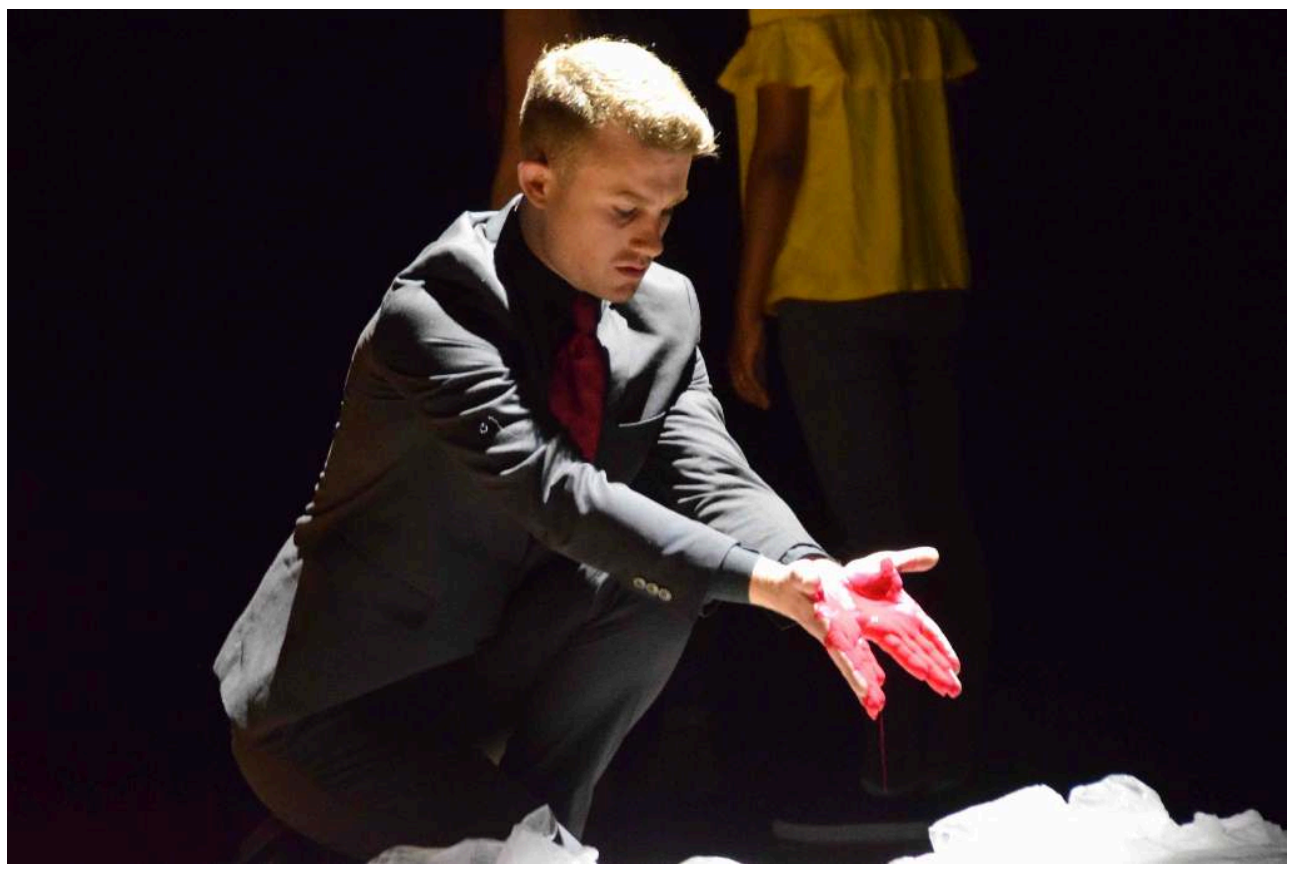

Septimus's death / sacrifice

203 The final ambivalent tableau displayed the synthetic image of "consciousness" as a "luminous halo," 163 painful and ecstatic, in the image of Clarissa's party: "Somehow it was her disaster - her disgrace. It was her punishment to see sink and disappear here a man, there a woman, in this profound darkness, and she force to stand here in her evening dress. (...) Odd, incredible; she had never been so happy." (Woolf, [1925] 2013: 173-74).

\section{Figure 15}

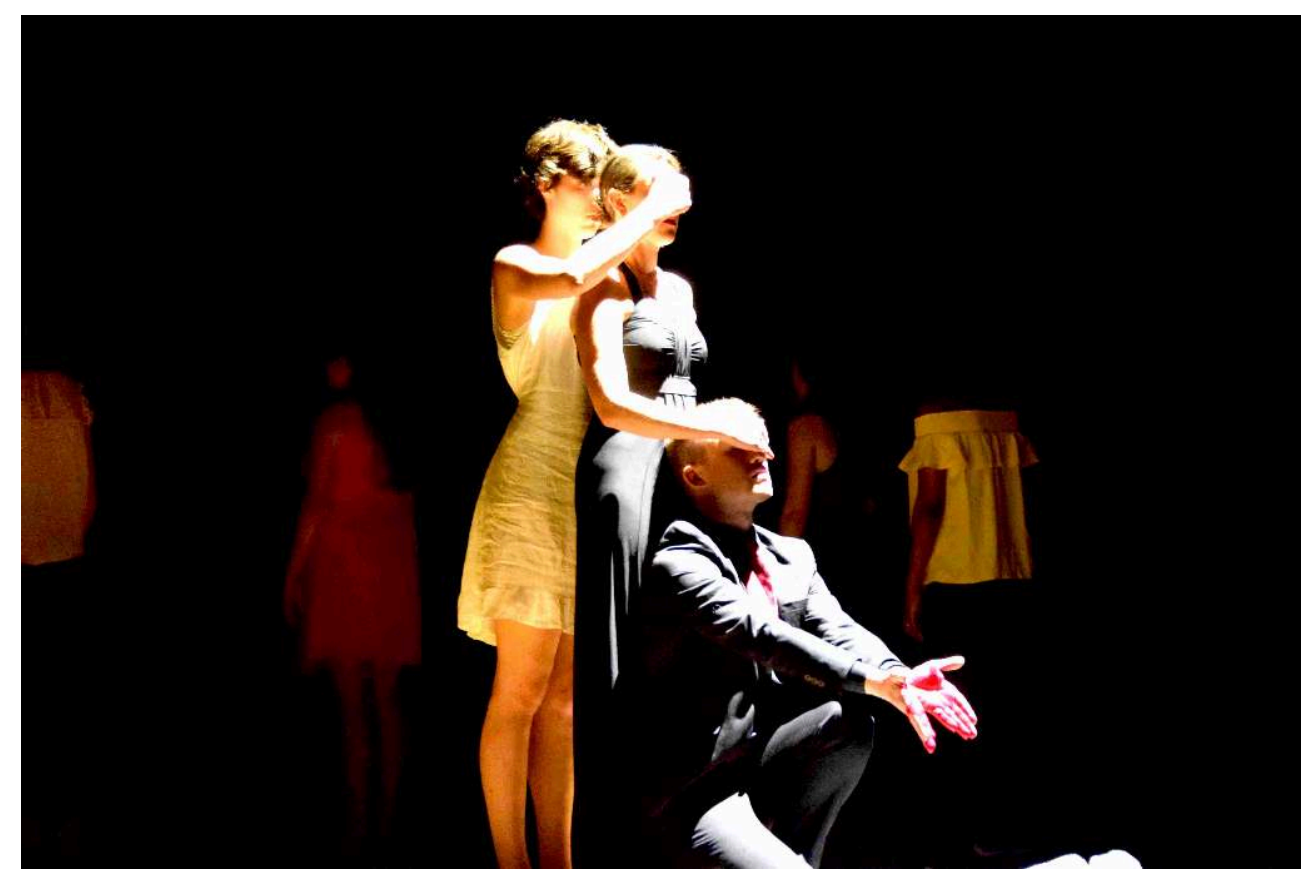

Epilogue: Claire, Clarissa and Septimus 
A revival of the TILLIT 2018 production was staged in September 2018 for the European Researchers' Night (Cap Sciences, Bordeaux). Two performances were given to illustrate the notion of "interpretive potential" and show its relevance to language and literature studies.

\section{Figure 16}

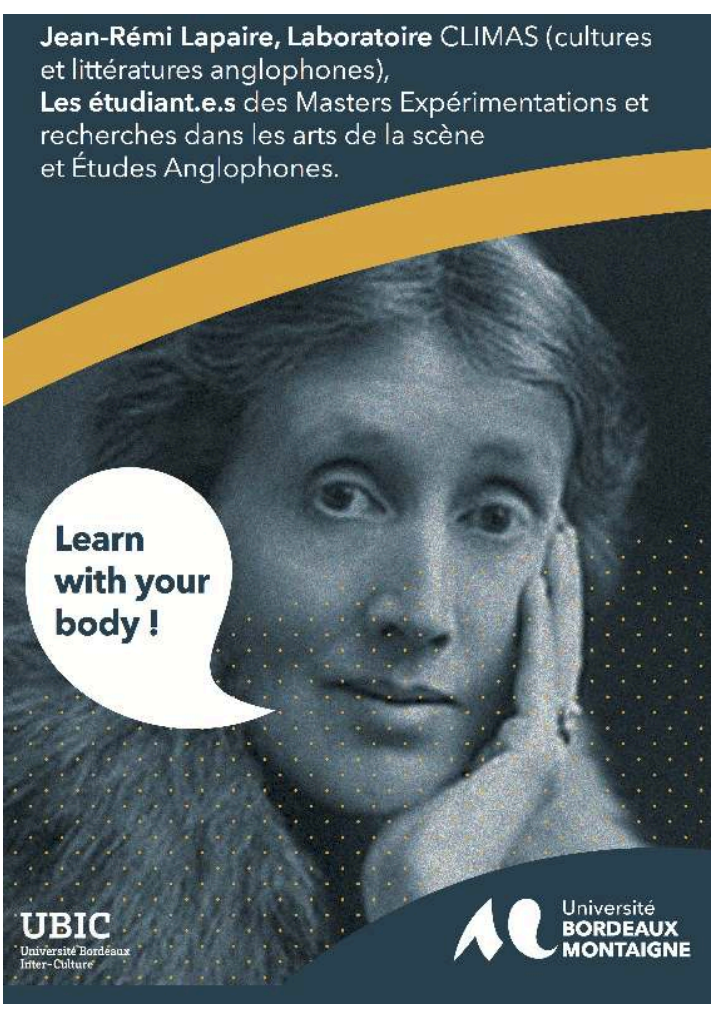

European Researchers' Night (2018)

\section{Student feedback}

All UBM students enrolled in the M.A. seminars ("The Choreorgraphy of Speech", "English for the Performing Arts") are expected to keep a learner diary, chronicling events and reflecting upon their "learning experience" during the seminars and workshops (Entries $1 \& 2$ ). Follow-up activities are systematically added (Entries 3 \& 4), which combine standard academic tasks (e.g. reading research articles, watching documentary films, performing short corpus studies or close reading exercises), and more creative exercises (e.g. compiling a biography in the form of a prose poem; rewriting or recycling literary material creatively). A set of weekly instructions is sent to all registered participants through the Moodle course management system. At the end of the semester, students upload the finished version of their work (typically "Diary of a Choreographer of Speech" or "Diary of a Drama Student") for assessment. They also fill an anonymous course evaluation questionnaire, where they can voice their feelings more openly about multimodality, performance and diary writing. 


\section{Diary of a Choreographer of Language}

Complete with illustrations

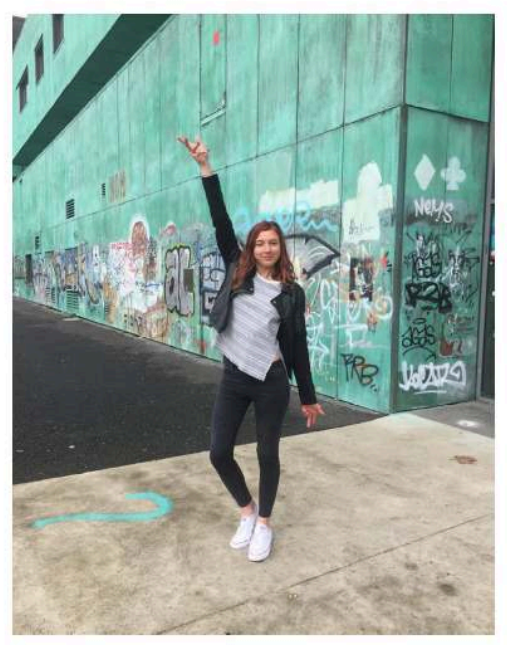

$\operatorname{Sarah} L^{\star \star \star \star}$

2018

\section{Diary of a Choreographer of Language}

\section{Complete with illustrations}
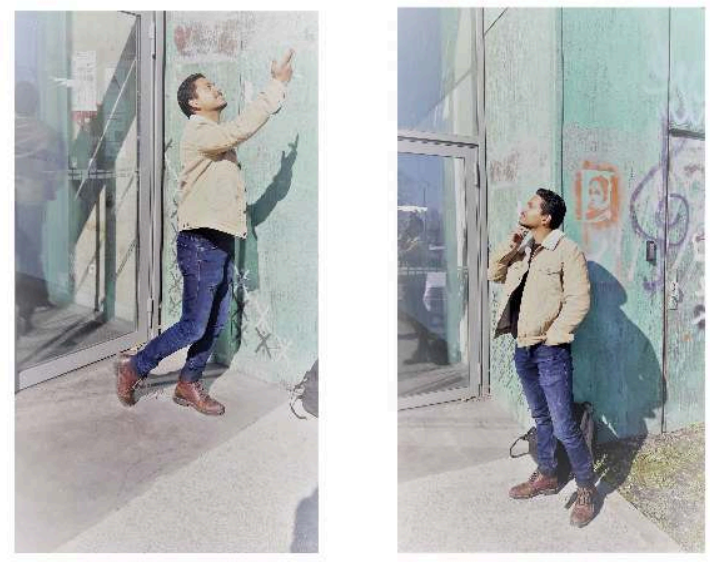

Ashley $\mathrm{M}^{* * *}$

2018

Learner diaries: Sarah's \& Ashley's cover pages

32 out (of 38) UBM students took the online survey. Responses were strickingly similar in both groups so the data was processed together. Answers diverged only in two areas: language proficiency and reflective journaling. As might have been expected, the drama 
students experienced occasional difficulty with oral instructions and written tasks in English, but all had used notebooks, sketchbooks or drama journals before, as part of their artistic training. English majors, on the other hand, had no issues with using a foreign language, but none had ever kept a learning diary (or a journal of any kind) before. Interestingly, some respondents expressed regret that no provision had been made for the diaries to be circulated among participants. As a result, insights and impressions had not been properly shared.

On a scale of 1 (low) to 4 (high), 30 respondents expressed the view that exploring the choreography of speech physically and engaging in bodily acts of literary interpretation were (highly) meaningful. 28 defined their experience during the workshops with oliver Borowski as truly exciting and empowering: "My favorite research seminar this year on the master's course - altogether a beautiful experience"; "A unique, unforgettable experience that will stick in my mind for years to come"; "Incredibly thoughtprovoking. I hope I can use some of the concepts and activities we learnt when I become a language instructor myself"; "I wish the other seminars adopted the same teaching format"; "What I liked best was being creative and engaging in group activities"; "I think you can never be bored with Oliver. Each activity is different from the previous one. It is playful and instructive at the same time"; "I particularly liked the way Oliver explained how we should perform, mentally connecting with the audience and imagining that some camera, somewhere, was filming us"; "Oliver clearly wanted us to do something bigger than we thought we might do. Artistic life is a demanding life"; "Oliver made us feel confortable and was very supportive of the work we did. He systematically took our ideas into account and built on the little we had to offer, however awkward and tentative. It would have been much easier for him (but not so good for us) to impose his own views." There were very few critical comments: "Some of Oliver's instructions were unclear"; "There was confusion and a certain fuzziness, at times"; "I wish Oliver had showed us what to do, instead of just telling us: gesture, as was pointed out in class, belongs to the world of doing and displaying"

For want of space, the rich data extracted from the 38 learner diaries - some totaling 40 pages - will not be analyzed here. Only short, qualitative samples will be supplied that provide precious insight into how the students dealt with the process of (character) interpretation:

Week 8 - ENTRY 2

a. Use the excerpts from Virginia Woolf's novel (Mrs Dalloway) to illustrate one notion or process mentioned in the TED-ED animation 'Why you should read Virginia Woolf:

"He was right there. The last shells missed him. He watched them explode with indifference." (Woolf 1925, Mrs Dalloway). Delving into a traumatic episode of the past. (Amber)

"What business had the Bradshaws to talk of death at her party? A young man had killed himself. And they talked of it at her party-- the Bradshaws, talked of death. He had killed himself--but how? Always her body went through it first, when she was told, suddenly, of an accident; her dress flamed, her body burnt. He had thrown himself from a window. Up had flashed the ground; through him, blundering, bruising, went the rusty spikes. There he lay with a thud, thud, thud in his brain, and then a suffocation of blackness. So she saw it. But why had he done it? And the Bradshaws talked of it at her party! She had once thrown a shilling into the Serpentine, never anything more." (Woolf 1925, Mrs Dalloway). Interior monologue. (Eva)

b. Pick three characters (in the script) that you feel especially drawn to. If you were asked to stage the play, how would you characterize their voice, tone \& delivery 
style? What would their characteristic facial expressions, demeanor and kinetic style (Fr. signature motrice) be like?

Miss Kilman - Stiff, bitter and an angry look on her face. Sudden moves, quick, fast. Eyebrows frowned. (Sarah)

Septimus -"A voice spoke from behind the screen. Evans was speaking. The dead were with him." " 'I have-I have,' he began, 'committed a crime-" I can picture him hearing voices with a demented look on his face - in expressionist fashion. Thinks he knows everything and that no one is worthy of trust. I can imagine him being paranoid and trapped in his own mind. (Charlotte)

Clarissa Dalloway - Center of consciousness, central character, smart and bright. Her tone and delivery style must reflect the duality in her character. I think she should look lost, with flashes of despair, then light up with joy at other times. "He has escaped. Are we not all prisoners (...) What an extraordinary night!" (Elsa)

Evans - He has no line in "Performing Mrs. Dalloway". This character is only a presence, a memory. It would be quite interesting to stage him. If I were to do so, I would focus on fluid movements. I would choose to be far from the audience and to never face it. That way, I would evoke the idea of someone not completely there, someone dead. (Faustine)

c. Think of the kinetic activity that might accompany the delivery of the lines below. Try to describe the movements with simplicity but accuracy.

"Messages passing from the Fleet to the Admiralty."

A movement of the head, from left to right, to enact the notion of movement from one place to another. (Maureen)

"The ebb and flow of things."

Vertical palms, large movements from left to right. (Sébastien)

"The cabs, the people, and the parks."

Head and body turning left and right, disorderly, as if lost or surrounded and worried, erratic. (Ines)

"This party is an offering. This is my gift to the world."

Hands raised in the air, palm upwards, metaphorically holding an abstract object (the party) then iconically offering it to the gods, the world, the spectators. (Amélie)

210 Week 10 - ENTRY 1

Did you feel bored or inhibited or confused at any particular time?

The voice projection exercises (javelin throws) were truly difficult for me but I enjoyed watching the others doing it! (Jeni)

I felt a little confused during the first two workshops. The exercises were particularly hard for me and I wasn't fully able to perform them. I liked how it turned out though and I was given the chance to appear and act on a real stage, at the Performing Arts Centre, something I had never done before in my country (Slovakia) (Zuzana)

\section{Week 11 - ENTRY 2}

Confirm your choice of an act (I Performing Mrs Dalloway) and lines to memorize for next week's workshop sesssion. Which words and images strike you most? Do you need guidance or would rather improvise? Have you chosen partners yet? How will you organize your work? How would you characterize your acting style?

My favorite act is Act 2 - The Notebook, because the reader or spectator gets to know what goes on inside the characters' minds as well as their relationships without the chorus interfering. However, Act 1 - The Party is richer, in dramatic terms: there are more characters and even more importantly, more interactions. (Maureen)

I decided to focus on the last lines of the Chorus at the end of Act 1. Guidance would probably be useful, but I will first have a go with my group and we'll see what happens then! The image of Death strikes me most. I like the idea that Mrs. Dalloway's private thoughts are expressed through different voices: the perspective is internal and external, an our position in space reflects this. On a more practical note, we will see each other just before the class and organize ourselves from there with Elsa, Sarah, Jade and Ines. I'm not sure yet what my acting style will be like. (Marie) 
Performing Mrs Dalloway: an evocation (in prose, verse or any form you choose).

I did not feel particularly comfortable. I guess I am too self-conscious. None of us really looked too good, compared to the drama students who clearly knew what they were doing on the stage, were genuinely creative and did some real acting (which I feel we didn't). However, I know I should be doing more of this kind of work. Maybe I should join a theater workshop or something of the sort. (Sara)

At first, I did not find the story engaging. But as soon as I joined one of the "chorus cells", and after watching the other groups perform, in different styles, with different ideas, I realized how rich and powerful the novel was. It became clear to me that the text could be interpreted in multiple ways, depending on our own emotional understanding of characters and situations. (Léa).

Performing Mrs Dalloway enabled me to "experience" Woolf's work and not just "study" it, in a conventional way. It made it much easier for me to enjoy the novel, which I am not sure I would have read otherwise. The workshops and their strong focus on the body enabled me to have a better understanding of the characters. I imagined their body language, their personality and demeanor through the hints present in the text, which I am sure, I would have never done in class, let alone in the privacy of my home! (Hortense)

An atmosphere, I can't properly describe, was created on the stage. The aesthetics were also very clever. The light and the staging were very simple, beautiful and incredibly powerful. (Fanny)

The last workshop was incredible. I am so glad that we finished this course with this workshop. It summed up everything. I enjoyed every moment of it and for sure I would love to live through this experience again and again. (Sofiia)

People march, stand in a line then scream. Soldiers draw their guns and kill. The party! Music, lights, people. Mrs. Dalloway has never been so happy. Septimus knows everything, and everyone knows he's dead. Only she knows he has escaped. In this strange, ambivalent and traumatic setting (...) Oliver Borowski tells us to try, he tells us to dare. As there are many possible interpretations, we are free to work on bodily moves. We design a piece of choreography, realize it does not work and try something else. Things start to feel more "natural". We act, we speak, but we also look and listen. Lots of bodies, lots of minds, lots of ideas. The more we are, the more creative we become. Each of us has a story to tell, something to express. It is both a personal and a collective experience. We are the words, we are the music, we are the chorus itself. (Benjamin)

213 The juniors at Lycée Bossuet (aged 16-18) had never kept a learner diary before. The following instructions were sent to them, after the second workshop:

(1) Sum up your feelings after the sessions (in just 3 words or with full sentences);

(2) Write a short piece about Performing Mrs Dalloway, in any form you choose, conventional or unconventional (i.e. plain or poetic, fluid or broken, connected or disconnected, with or without verbs and punctuation). You are welcome to mix different bits and pieces from the script with your own record, in collage fashion. You may also choose to compose a prose poem; (3) When you were asked to pick a character in Mrs Dalloway, which one did you choose, and which lines did you eventually learn?; (4) Anything you might want to add, scribble, or draw?

Only 10 (out of 40) replied: some probably felt too shy to write to a professional dancer and a university professor in English; others were simply too busy preparing for the demanding French literature paper which all Juniors are expected to take for the baccalaureate. The feelings most commonly reported were: interest; (initial) surprise or bewilderment; pleasure; general well being, and gratitude. Most acknowledged that they had actually learnt something about themselves, and had discovered a new physical approach to exploring literature in a foreign language:

Thank you for everything, again. That was an amazing experience, and we loved it so much. The first session was difficult but very interesting too. We didn't expect 
such a thing! We learned many things about our bodies, and our voices. (Julia, Katia, Lena);

We are delighted to have shared this experience. First of all, we found it very interesting to combine words with dance and movement. It is something we never do, and experimenting this with you was a pleasant discovery. Playing the characters in Mrs Dalloway enabled us to know more about them and about acting. The two afternoons we spent with you were very rewarding for both our personal experience of education and to enrich our understanding of language. Thank you for coming. (Claire, Victoire).

215 All expressed a willingness to explore the physicality of literary appreciation further, during their senior year:

Fun, interesting, original. Thank you so much for coming and teaching. We hope to see you soon for another workshop. (Jessica, Euan, Emma);

We are sending you a (virtual) bouquet, with (virtual) Champagne and a (virtual) chocolate box. We hope you'll like this (virtual) present as much as we liked your (real) workshop. (Aude, Pauline).

216 The pieces produced suggest that the approach has the potential to surprise and motivate learners:

Mrs Dalloway,

With this play,

We learned a new manner,

In few hours,

To live a language,

Whatever our age.

Thank you for everything,

We didn't expect such a thing!

(Julie, Katia, Lena)

217 Some pupils recycled material from the script to report the experience:

Bossuet in the middle of May,

The tests are nearly over,

The teachers, the students, the park,

The ebb and flow of things.

(Jessica, Euan, Emma)

Once upon a time, Mrs Dalloway said she would buy the flowers herself. But then, pupils said that they would like to thank Melissa and Jean-Rémi with the nicest bouquet of flowers ever made to this day. Nicer than Richard Dalloway's flowers to Clarissa. Because they smiled better than Mrs Dalloway, and were better dancers too. (Aude, Pauline)

One day Miss $\mathrm{B}^{* * *}$ told her pupils: "You are going to discover the power of body language, using sentences from Mrs Dalloway - a work by Virginia Woolf. The pupils did (all sorts of) exercises to occupy the space with dancer's help, Melissa Blanc. They felt like professional dancers, with an instructor who was a bit strict but showed them what to do. But the most important thing is that Melissa believed in us. Jean-Rémi too believed we had the potential to perform (a difficult piece) and he was amazed by the result and the energy that we invested. Melissa and Jean-Rémi helped us to open up our artistic minds and speak with a better accent. (Claire, Victoire)

218 Finally, some students used "creative re-elaboration" (Lapaire \& Duval 2017) to map Mrs Dalloway's world onto their own:

[Students are Septimus. Teachers are Mrs Dolloway].

The student: I am falling. I was standing on a cliff, with teachers screaming over me. Now I am raising my hands, like some colossal figure - a giant mourner- then pressing my hands to my forehead, furrows of despair on my cheeks, seeing legions 
of tests and exams. Yet I am now alive. Let me rest still! Why should I suffer? I was happy in my dream.

The teacher: I am giving a lesson this afternoon [Speaking to herself]. Oh dear, it is going to be a complete failure. Why am I doing these things? Why? (Jessica, Euan, Emma)

In conclusion, the interpretive strategy that we propose - integrating reading, re-writing, and performance - has a strong motivating potential, which is conducive to language learning and literary appreciation. "Literature in the flesh" - if we may call it so - can be used to develop oral and written skills creatively, facilitate understanding, increase levels of student attention and engagement.

\section{Figure 18}

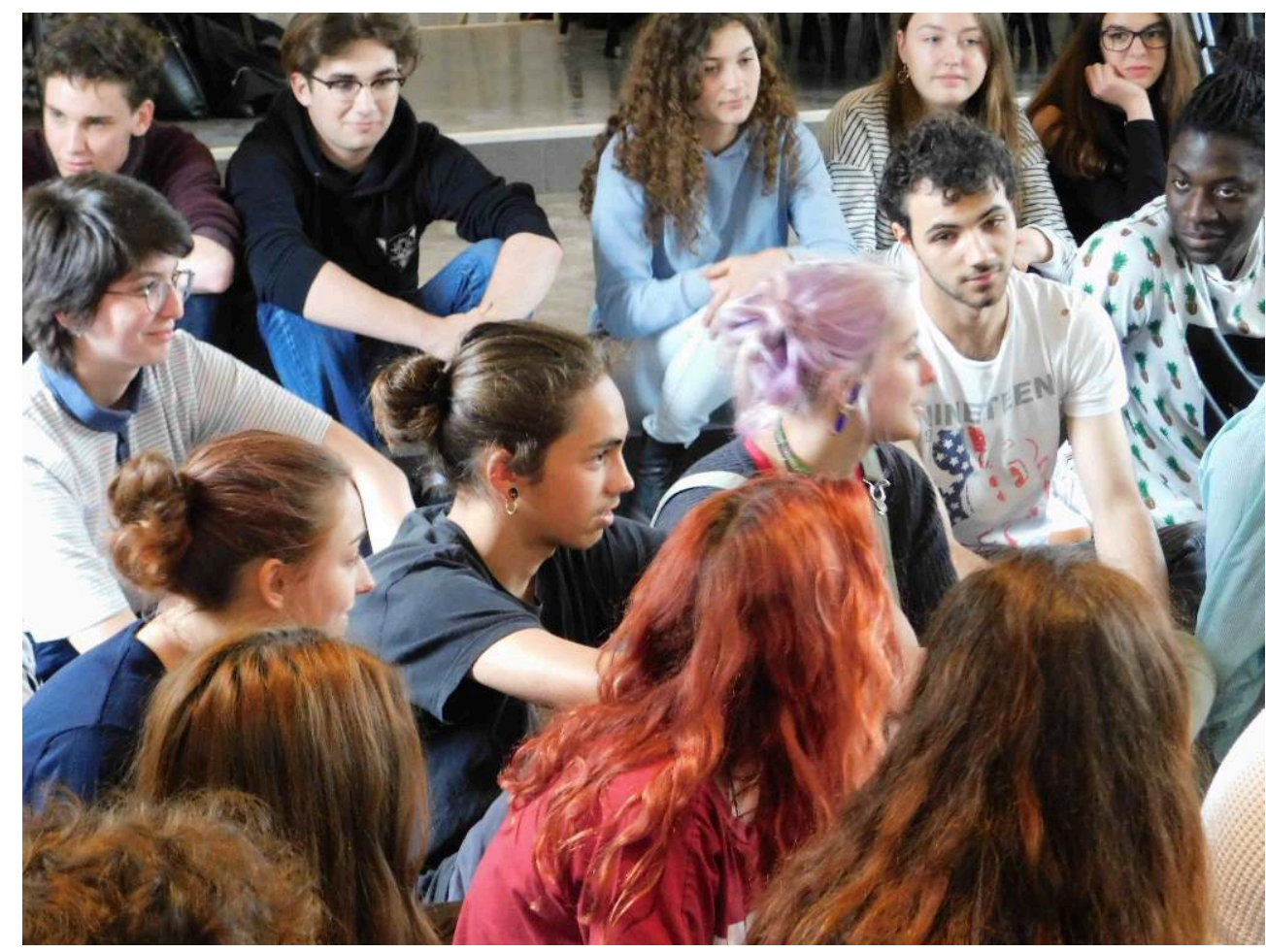

Student attention: listening to what others have to say 


\section{Figure 19}

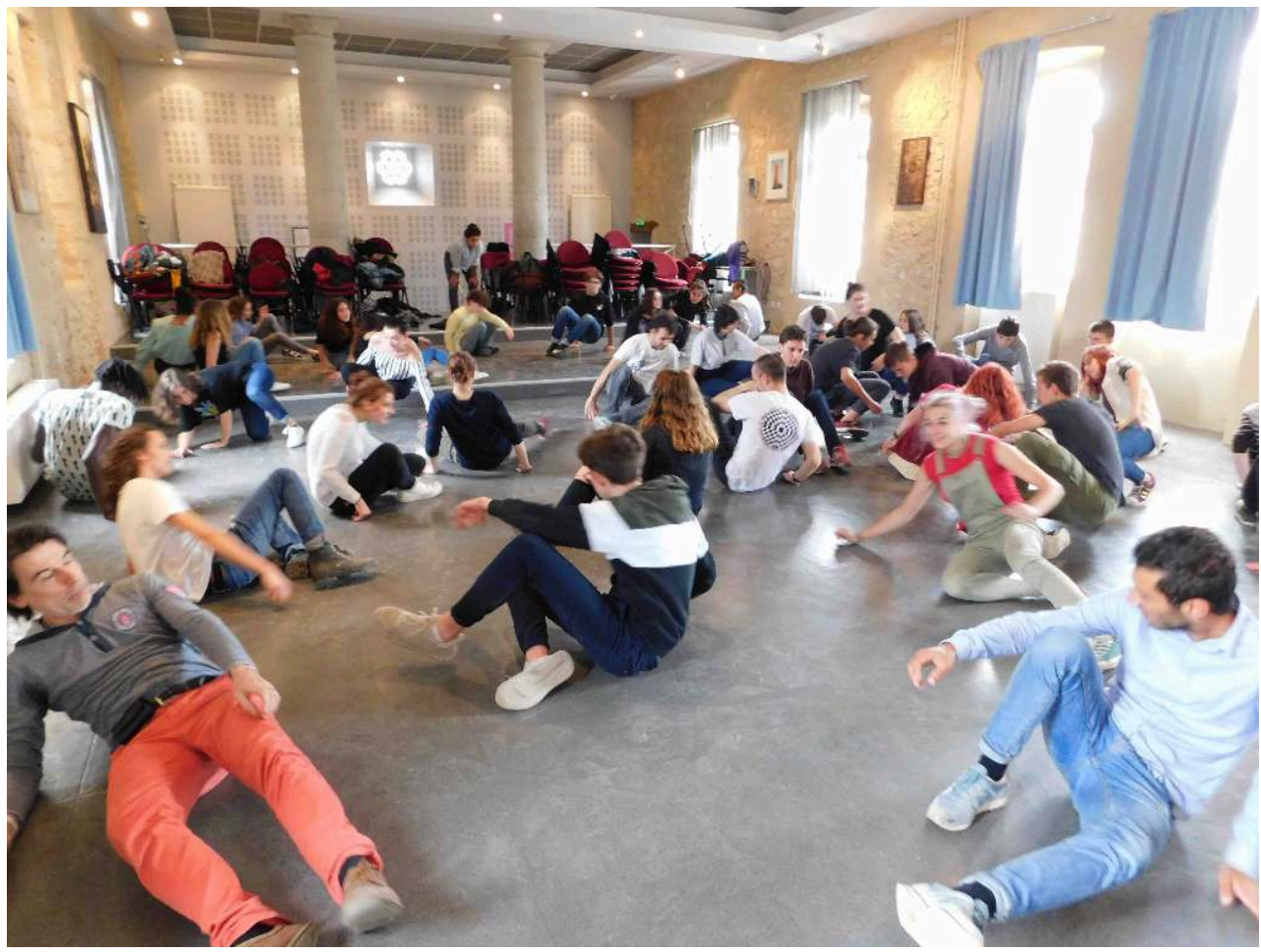

Student engagement: total physical responses to literary stimuli

\section{Moments of acting: TILLIT 2018 highlights}

Teatro in Lingua, Lingua in Teatro (TILLIT) is a student drama Festival directed Pr. Marco Pustianaz from Dipartimento di Studi Umanistici, and supported by Università degli Studi del Piemonte Orientale (UPO). 
Figure 20

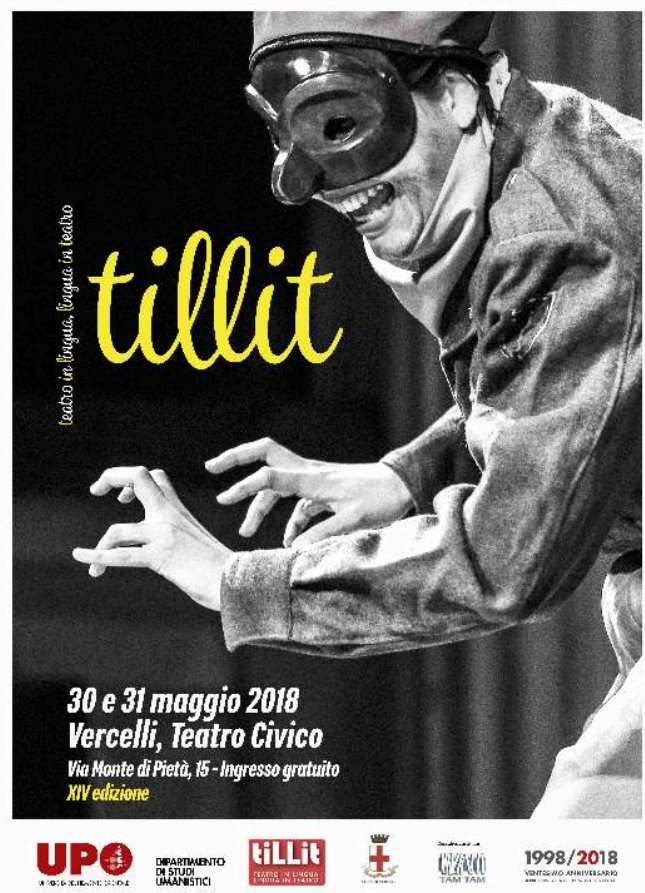

TILLIT 2018 Poster

221 The 2018 edition was held on 30-31 May 2018 at Teatro Civico, Vercelli, Italy. The performers were: Jade Aguire, Léa Boyault, Edward Hamp, Charlotte Haroun, Benjamin Helary, Sarah Lannoy, Jeni Peake, Ines Sebbah, Katleen Perez de Carvasal, Marie Munch, Pierre Surbled (MA in English Language and Literature Studies, UBM); Clémence Biensan, Chloé Dagois, Claire Gabriel (MA in performance studies, UBM). Local authorities insisted that a name be given to the travelling theatre company: "Choreographers of Speech" was an obvious choice, in reference to the M.A. seminar taught at UBM - The Choreography of Speech: Introducing Gesture Studies. 
Figure 21

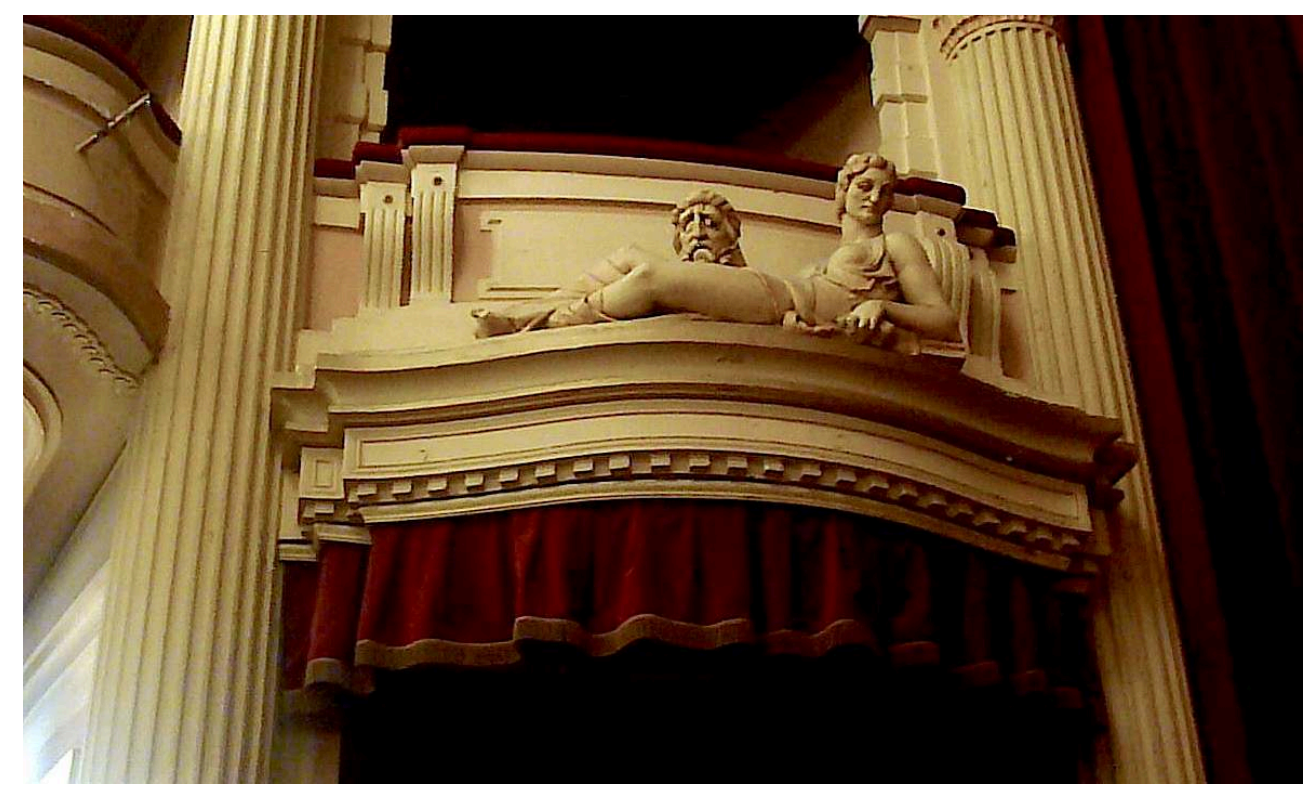

Teatro Civico di Vercelli - House left

Figure 22

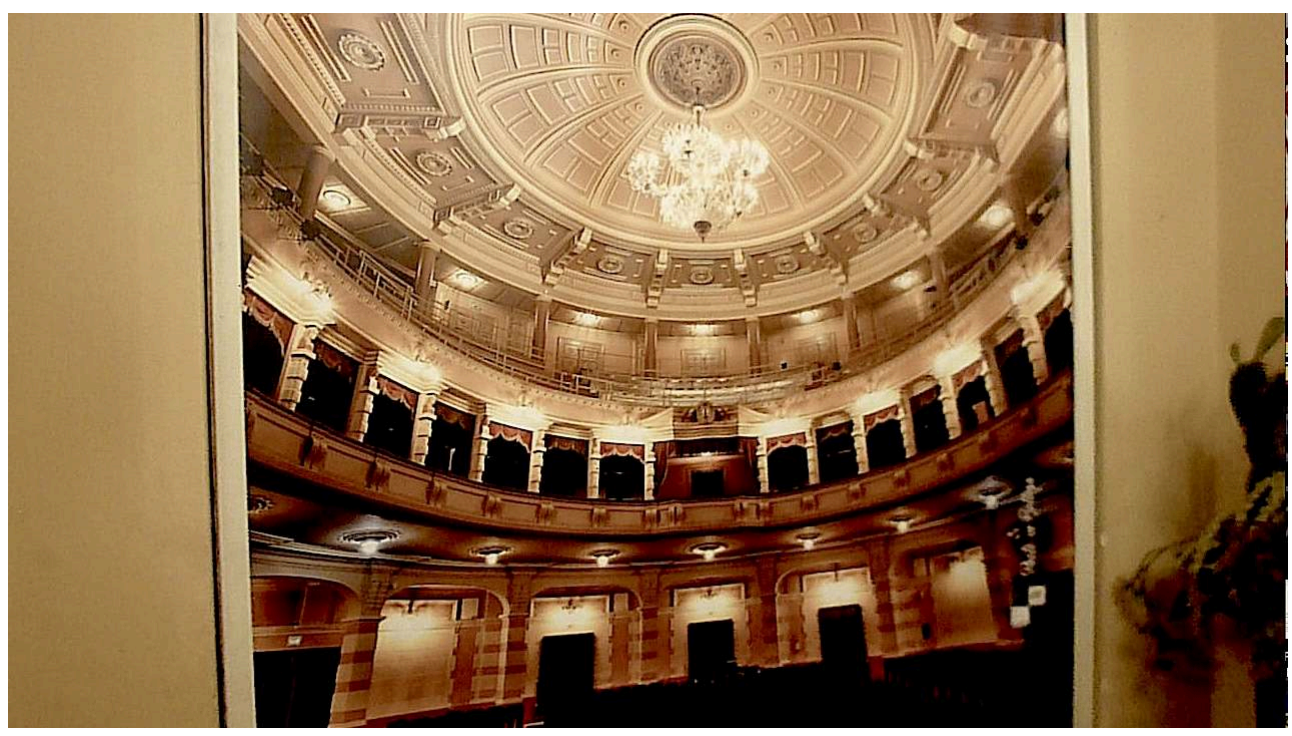

Teatro Civico di Vercelli - Upper galleries 
Figure 23

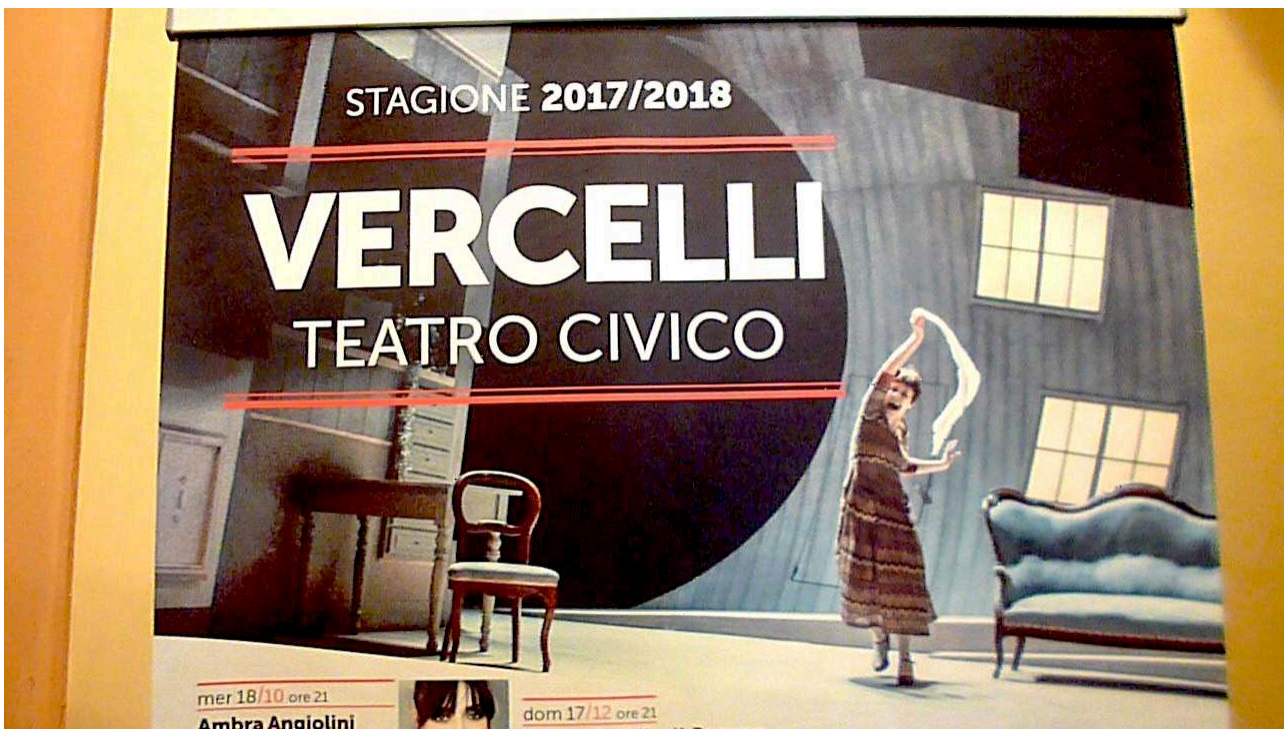

Teatro Civico di Vercelli - Before the Stagione ends

No sets, no props, no digital backdrop were needed: the stage was kept entirely bare. A few sound effects were used however, but sparingly: distant gunfire (Prologue); party music (Act 1); birds chirping (Act 2); war explosions (Act 3) and "Big Ben striking (...) irrevocable"164 (Epilogue).

Figure 24

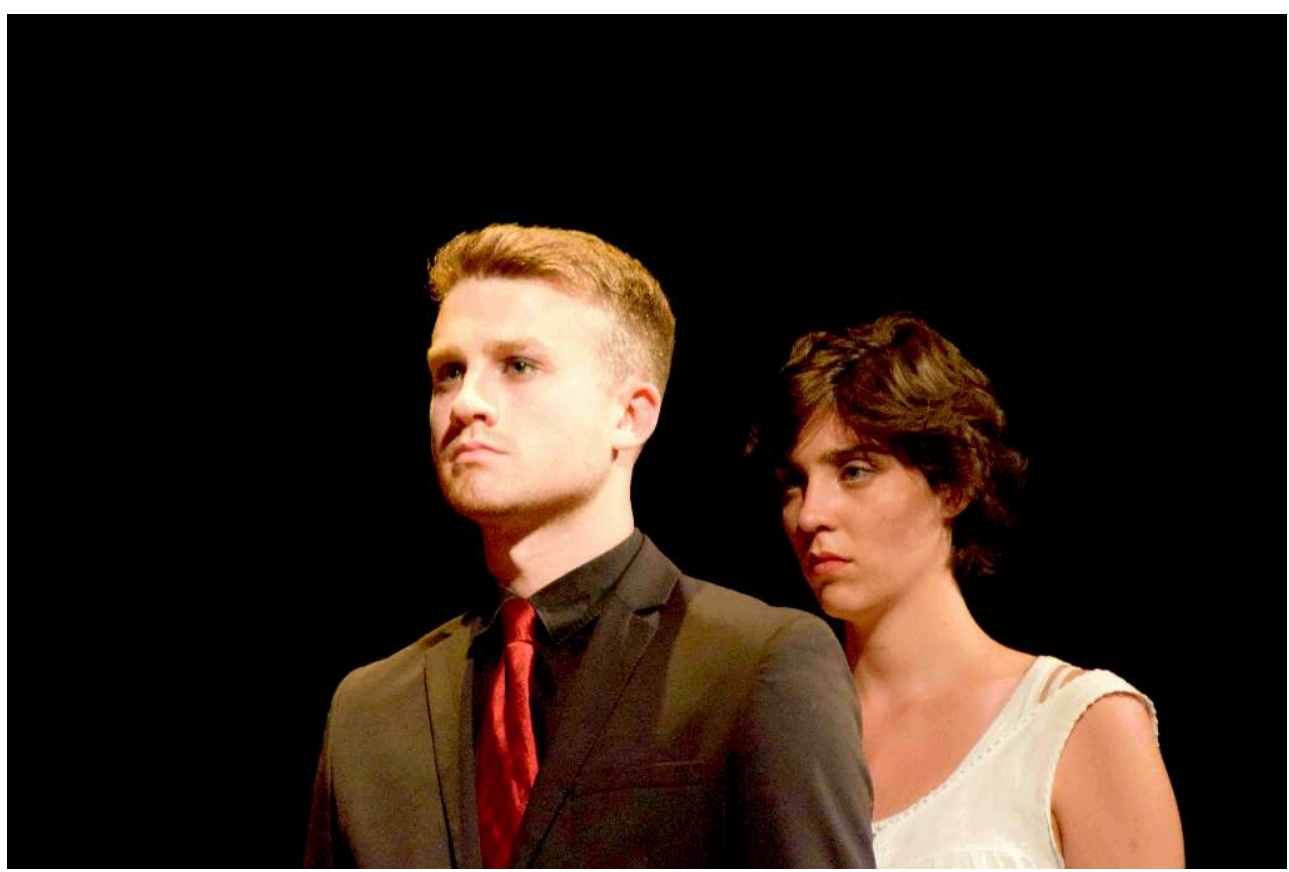

"I must tell the whole world!" (Prologue) 
Figure 25

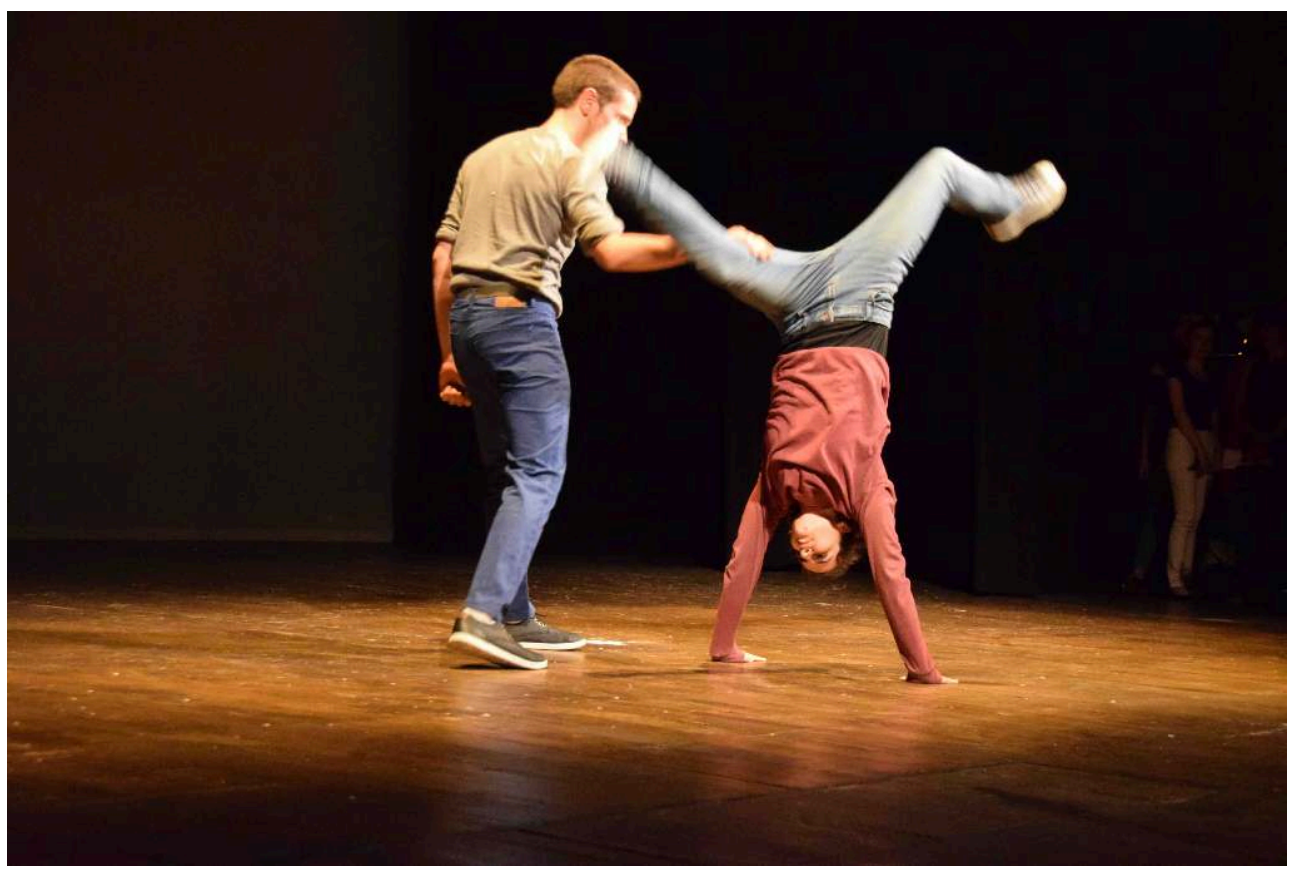

Children in the park (Act 2) ${ }^{165}$

Figure 26

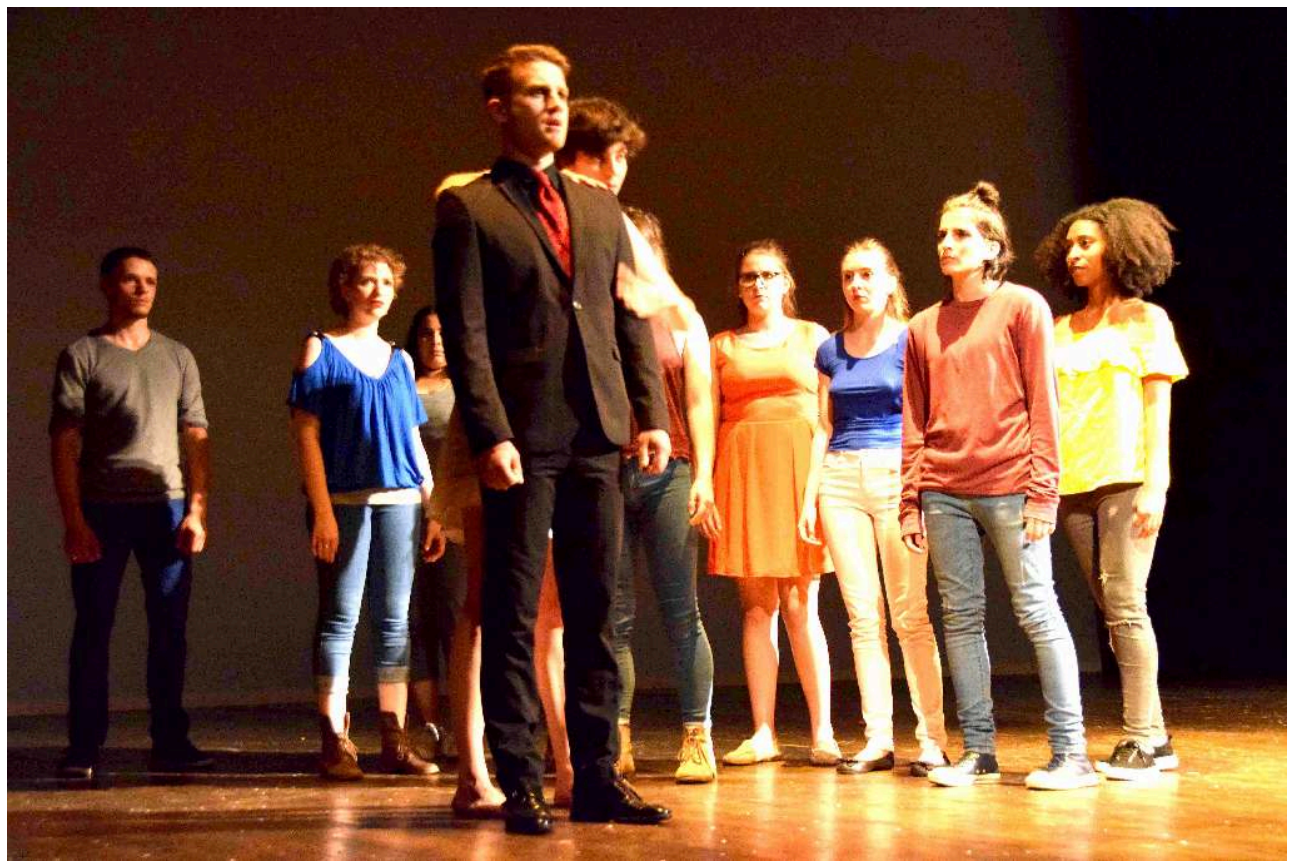

"I am not afraid. Love, trees, there is no crime!" (Act 3) 
Figure 27

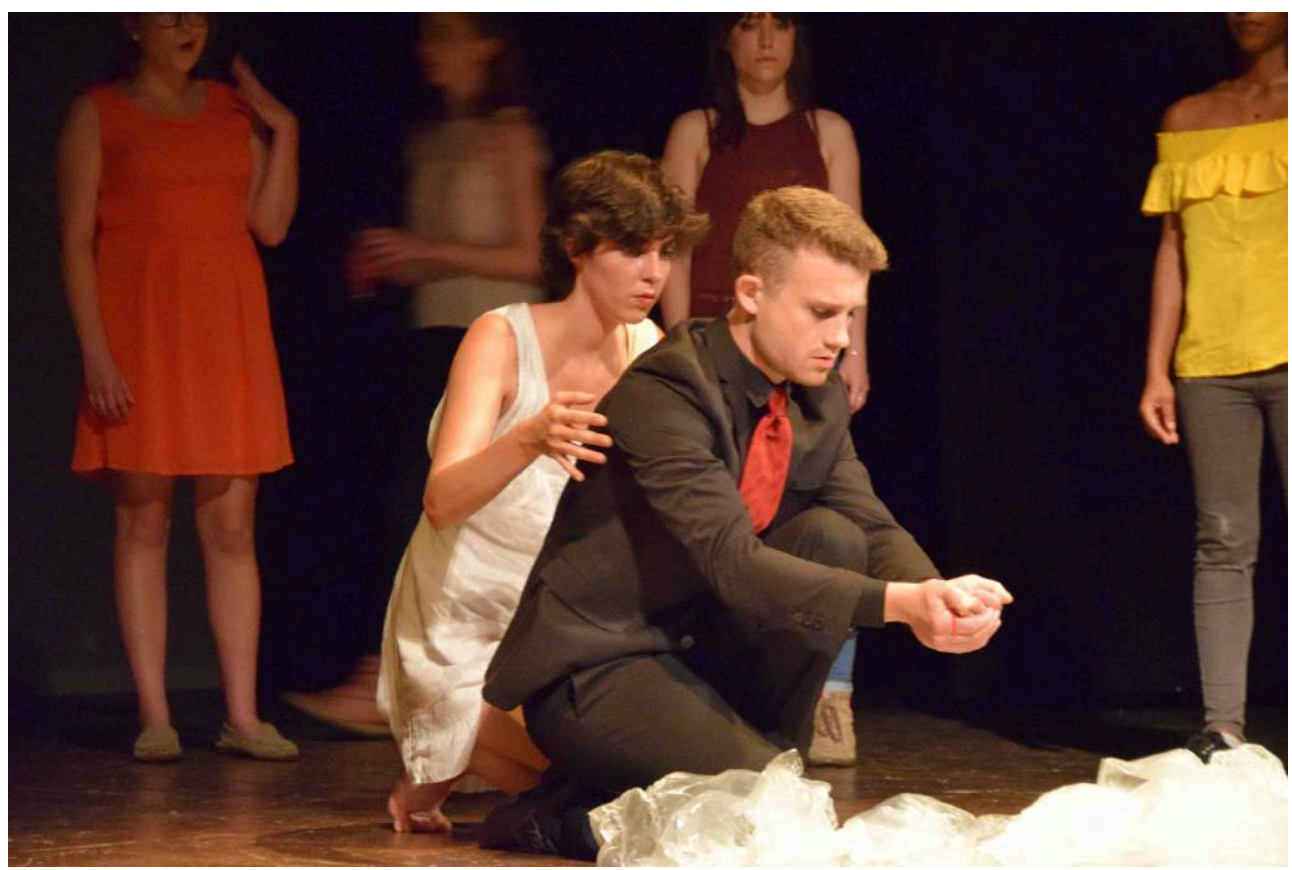

Transubstantiation: party wine has turned into Septimus's blood

Figure 28

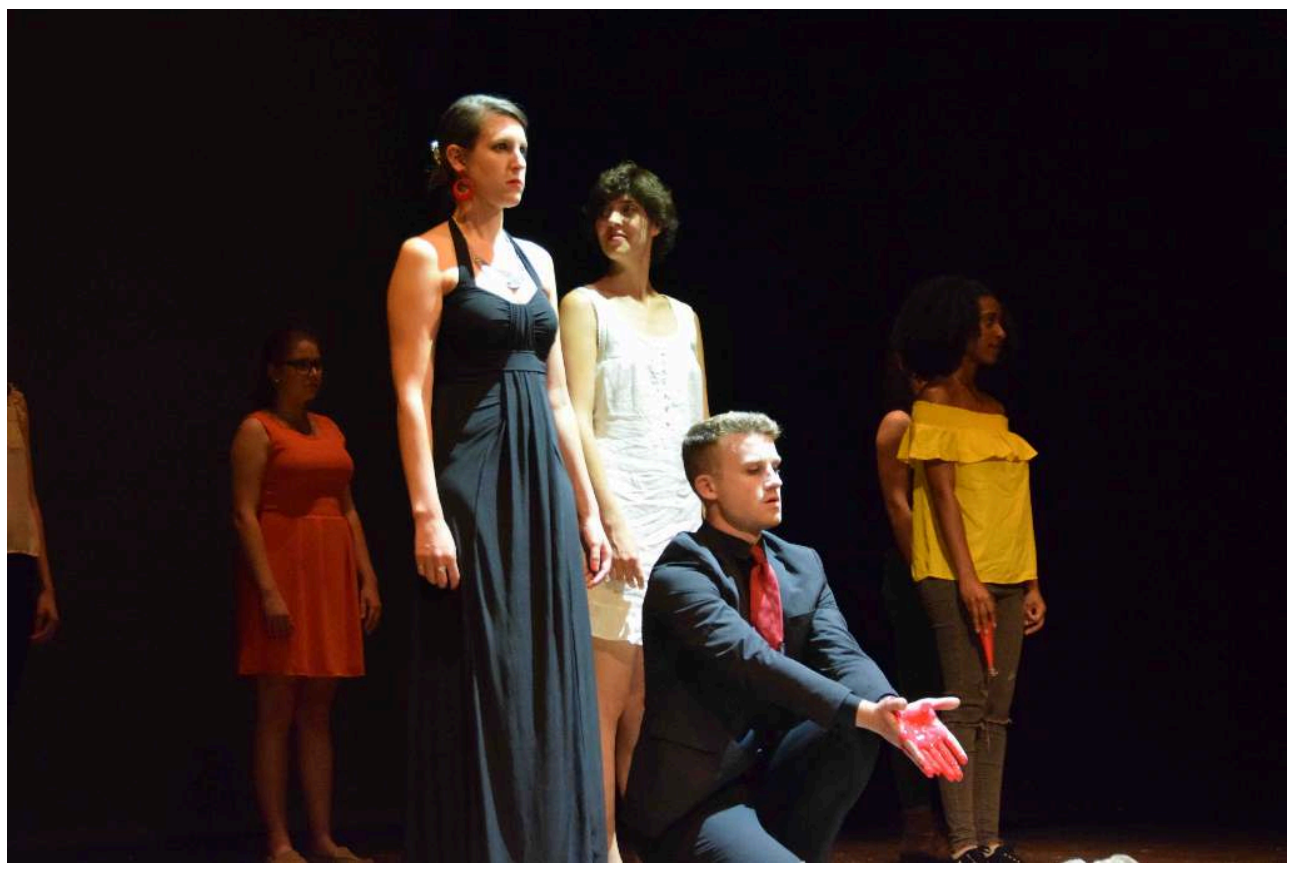

Closing tableau with Clarissa and Septimus 


\section{BIBLIOGRAPHY}

Abrams, M.H. A Glossary of Literary Terms. Third Edition. New York: Holt, Reinhart and Winston, Inc., 1971.

Baldt, Erika. “Abjection as Deviance in Mrs. Dalloway.” VWM (Virginia Woolf Miscellany), Number 20, Fall 2006, pp. 13-15.

Bennett Smith, Susan. "Reinventing Grief Work: Virginia Woolf's Feminist Representations of Mourning in Mrs. Dalloway and To the Lighthouse." Twentieth Century Literature. vol. 41, No. 4 (Winter, 1995), pp. 310-327

Bethea, Arthur. "Septimus Smith, the War-Shattered Christ Substitute in Mrs Dalloway." The Explicator, Volume 68, Issue 4, 2010, p.p. 249-252

Boxal, Peter. The Value of the Novel. New York, NY: Cambridge University Press, 2015.

Boxal, Peter. "Mrs Dalloway. Novel by Virginia Woolf." Article written for Encyclopedia Britannica and proposed on 16 March 2017 Retrieved from: https://www.britannica.com/topic/MrsDalloway-novel-by-Woolf Access on 06.07.2018.

D’Arcy, Sara. "Mourning, gender melancholia, and subversive homoeroticism in Virginia Woolf's Mrs Dalloway and Michael Cunningham's The Hours." Leitura Flutuante, n. 4, 2012, pp. 43-58.

DeMeester, Karen. "Trauma and Recovery in Virginia Woolf's Mrs. Dalloway." MFS Modern Fiction Studies, vol. 44 no. 3, 1998, pp. 649-673.

Diasnas, Hervé. “21e Migration 7.” Vol chorégraphique, interprété par l’Ensemble Chorégraphique Contemporain d'Envol, Les Plateaux 2010, Biennale du Val de Marne, 2010. Retrieved from: https://www.youtube.com/watch ?v =MfEiJetiGt8\&app =desktop Access on 04.07.2018

Dianas, Hervé. "Quelques mots sur le vol dansé." Extrait de la conférence "Arts du mouvement et \& Sciences: un espace commun?" Soirée 20 ans Danse-Etudes de l'INSA-LYON 1, Théâtre Astrée de Villeurbanne, 06.12.2011. Retrieved from: https://vimeo.com/69758035 Access on 04.07.2018

Edmondson, Annalee. "Narrativizing characters in Mrs. Dalloway." Journal of modern literature, 36.1, 2012, pp. 17-36.

Flint, Kate. Introduction to The Waves by Virginia Woolf. London: Penguin Classics, 1992, pp. ixxxxviii.

Goffman, Erving. “The Interaction Order,” American Sociological Association, 1982 Presidential Address, American Sociological Review, vol. 48, No. 1, Feb. 1983, pp. 1-17.

Henke Suzette A. "Mrs Dalloway: the Communion of Saints.” In: Marcus Jane (ed.) New Feminist Essays on Virginia Woolf. Palgrave Macmillan, London, 1981, pp. 125-147.

Herbert-Read, James E. Understanding how animal groups achieve coordinated movement. Journal of Experimental Biology 2016 219: 2971- 2983; doi: 10.1242/jeb.129411

Jakobson, Roman, “On Linguistic Aspects of Translation”, in Brower, (ed.), On Translation, Cambridge, MA: Harvard University Press, 1959, pp. 232-239.

Lapaire, Jean-Rémi. « The choreography of time : metaphor, gesture and construal ». In Gabriel, Rosangela. ; Pelosi, Ana Cristina Linguagem e cognição : emergência e produção de sentidos.

Florianópolis : Insular, 2016, pp. 217-34. 
Lapaire, Jean-Rémi. « La kinéflexion : produire, exhiber, partager des actes vivants de pensée », Intellectica, $2017 / 2, \mathrm{n}^{\circ}$ 62, 2017, 193-224.

Lindgren, Robb, Johnson-Glenberg, Mina. "Emboldened by Embodiment: Six Precepts for Research on Embodied Learning and Mixed Reality." Educational Researcher, 2013 42, 445-442.

O’Halloran, Kay, Tan, Sabine \& Wignell, Peter. “Intersemiotic Translation as

Piazzoli, Erika. Embodying Language in Action. The Artistry of Process Drama in Second Language Education. Cham : Palgrave Macmillan, 2018.

Krouse, Tonya. Sexual Deviancy in Mrs. Dalloway: The Case of Septimus Smith, VWM (Virginia Woolf Miscellany), Number 20, Fall 2006, pp. 15-17.

Lanone, Catherine. “The Non-Linear Dynamics of Virginia Woolf's London: from Elation to Street Haunting." Caliban, 25 | 2009. Retrieved from: http://journals.openedition.org/caliban/1639 Access on 05.07.2018.

O'Halloran, Kay L., Tan, Sabine and Wignell, Peter. Intersemiotic Translation as Resemiotisation : A Multimodal Perspective. Signata [Online], 7 | 2016. Retrieved from : URL : http:// journals.openedition.org/signata/1223 Access on : 31.08.2018.

Quintilianus, Marcus Fabius. De institutione oratoria [92]. An English translation by E.M. Butler. London: William Heinenman, 1920.

Schowalter, Elaine. "Mrs Dalloway: exploring consciousness and the modern world." Article written for The British Library, published 25 May 2016. Retrieved from: https://www.bl.uk/20thcentury-literature/articles/exploring-consciousness-and-the-modern-an-introduction-to-mrsdalloway Access on 23.01.2018.

Streeck, Jürgen. Gesturecraft. The manu-facture of meaning. Amsterdam / Philadelphia : John Benjamins, 2009.

Weiner, Albert. The Function of the Tragic Greek Chorus. Theatre Journal, vol. 32, No. 2 (May, 1980), pp. 205-212.

Woolf, Virginia. Mrs Dalloway. London: HarperCollins, [1925] 2013.

Woolf, Virginia. The Common Reader. First Series. Reprint. New York: Harcourt, [1925], 1984.

\section{NOTES}

1. Virginia Woolf, The Common Reader- Montaigne ([1925] 1984: 63].

2. What is suggested in both the original novel and the stage adaptation, is that sarcasm and backstabbing are inseparable from wit, good manners and social niceties in educated circles: "He was a thorough good sort; a bit limited; a bit thick in the head; yes, but a thorough good sort. Whatever he took up he did in the same matter-of-fact sensible way; without a touch of imagination, without a spark of brilliancy, but with the inexplicable niceness of his type. He ought to have been a country gentleman - he was wasted on politics. He was at his best out of doors, with horses and dogs." (Mrs Dalloway, [1925] 2013: 69)

3. "They should begin by analyzing each verse, then give its meaning in different language, and finally proceed to a freer paraphrase in which they will be permitted now to abridge, now to embellish the original, so far as this may be done without losing the poet's meaning (...) The people who handles it successfully will be capable of learning everything." (Quintilian, De institutione oratoria, Book II, ix-2-3) 
4. Mrs Dalloway, [1925] 2013: 2. "For it was the middle of June. The War was over, except for some one like Mrs. Foxcroft at the Embassy last night, eating her heat out because that nice boy was killed and now the old Manor House must go to a cousin; or Lady Bexborough who opened a bazaar, they said, with the telegram in her hand, John, her favourite, killed; but it was over; thank Heaven - over. It was June."

5. Mrs Dalloway, [1925] 2013: 6-7. "(A)ll this; the cabs passing (...) what she loved was this, here, now, in front of her (...) somehow in the streets of London, on the ebb and flow of things, here, there, she survived."

6. Mrs Dalloway, [1925] 2013: 1 . This is the sentence that actually opens the novel, although it is not used as a direct exclamation. Lucy remembers instructions that must have been issued earlier by Mrs Dalloway, upon leaving the house.

7. Mrs Dalloway, [1925] 2013: 1. "And then, thought Clarissa Dalloway, what a morning - fresh as if issued to children on a beach. What a lark! What a plunge!"

8. Mrs Dalloway, [1925] 2013: 154. "The Prime Minister was coming, Agnes said: so she had heard them say in the dining-room, she said, coming in with a tray of glasses. Did it matter, did it matter in the least, one Prime Minister more or less?"

9. Mrs Dalloway, [1925] 2013: 61. "He had grown stranger and stranger. He said people were talking behind the bedroom walls (...) He saw things too."

10. Mrs Dalloway, [1925] 2013: 80. "There in the trenches (...) he developed manliness; he was promoted; he drew the attention, indeed, the affection of his officer, Evans by name (...) Evans was killed, just before the Armistice, in Italy."

11. Mrs Dalloway, [1925] 2013: 60. “(T)hat dead man Evans, whom she had only seen once for a moment (...) had seemed a nice quiet man; a great friend of Septimus's, and he had been killed in the War. But such things happen to every one. Every one has friends who were killed in the War." 12. Mrs Dalloway, [1925] 2013: 64. "A man in grey was actually walking towards him. It was Evans! But no mud was on him; no wounds; he was not changed. I must tell the whole world, Septimus cried (...) raising his hand like some colossal figure who had lamented the fate of man for ages in the desert alone with his hands pressed to his forehead, furrows of despair on his cheeks, and now sees the light on the desert's edge (...) with legions of men prostrate behind him he, the giant mourner, receives for one moment on his face the whole - "

13. Mrs Dalloway, [1925] 2013: 43. “'Peter! Peter!' cried Clarissa, following him out on to the landing. 'My party to-night! Remember my party to-night' she cried, having to raise her voice against the roar of the open air."

14. Mrs Dalloway, [1925] 2013: 33. "Her evening dresses hung in the cupboard. Clarissa plunged her hand into the softness, gently detached the green dress and carried it to the window (...) She would wear it tonight."

15. Mrs Dalloway, [1925] 2013: 32-33. "She was not old yet. She had just broken into her fiftysecond year."

16. Mrs Dalloway, [1925] 2013: 6. "She knew nothing; no language, no history; she scarcely read a book now, except memoirs in bed (...) Her only gift was knowing people, almost by instinct, she thought, walking on."

17. Mrs Dalloway, [1925] 2013: 157. "Oh dear, it was going to be a failure; a complete failure, Clarissa felt it in her bones (...) Why after all, did she do these things? Why seek pinnacles and stand drenched in fire?"

18. Mrs Dalloway, [1925] 2013: 113. "But suppose Peter said to her, 'Yes, yes, but your parties what's the sense of your parties?"'

19. Mrs Dalloway, [1925] 2013: 167. "It was a pity they lived in London - Richard and Clarissa. If only for Clarissa's health it would have been better to live in the country. But Clarissa had always been fond of society." 
20. Mrs Dalloway, [1925] 2013: 154. “The Prime Minister was coming, Agnes said: so she had heard them say in the dining-room, she said, coming in with a tray of glasses. Did it matter, did it matter in the least, one Prime Minister more or less?"

21. Mrs Dalloway, [1925] 2013: 123. “'Are you going to the party tonight?' Miss Kilman said. Elizabeth supposed she was going; her mother wanted her to go."

22. Mrs Dalloway, [1925] 2013: 123 "Elizabeth supposed she was going; he mother wanted her to go. She mustn't let parties absorb her, Miss Kilman said, fingering the last two inches of a chocolate éclair. She did not much like parties, Elizabeth said (...) 'I never go to parties," said Miss Kilman, just to keep Elizabeth from going. 'People don't ask me to parties (...) Why should they ask me? I'm plain, I'm unhappy"

23. Mrs Dalloway, [1925] 2013: 123. "She must not let parties absorb her, Miss Kilman said."

24. Miss Kilman's unattractiveness is also expressed in "beginning with this indignity - the infliction of her unlovable body which people could not bear to see" as well as in "She prayed to God. She could not help being ugly." Mrs Dalloway, [1925] 2013: 120.

25. Mrs Dalloway, [1925] 2013: 123. 'I'm plain, I'm unhappy.'

26. Mrs Dalloway, [1925] 2013: 120. "It is the flesh, it is the flesh," she muttered (...) trying to subdue that turbulent and painful feeling as she walked down Victoria Street."

27. Mrs Dalloway, [1925] 2013: 120. "She despised Mrs. Dalloway from the bottom of her heart." (See also p. 116).

28. Mrs Dalloway, [1925] 2013: 122. "Miss Kilman swelled and looked very plain, but Miss Kilman was frightfully clever."

29. Mrs Dalloway, [1925] 2013: 120. “(She was) struggling (...) with that violent grudge against the world which had scorned her, sneered at her, cast her off."

30. Mrs Dalloway, [1925] 2013: 123 “'I never go to parties,' said Miss Kilman, just to keep Elizabeth from going. 'People don't ask me to parties.' (...) She had suffered horribly. 'Why should they ask me?' she said 'I'm plain, I'm unhappy.' She knew it was idiotic."

31. Mrs Dalloway, [1925] 2013: 156."'How delightful to see you!' said Clarissa. She said it to everyone."

32. Mrs Dalloway, [1925] 2013: 56 "Clarissa came up, with her perfect manners, like a real hostess"

33. Mrs Dalloway, [1925] 2013: 156. "She was at her worst - effusive, insincere."

34. Mrs Dalloway, [1925] 2013: 6 "She sliced like a knife through everything; at the same time was outside, looking on. She had a perpetual sense, as she watched the taxi cabs, of being out, out, far out to sea and alone; she always had the feeling that it was very, very dangerous to live even one day."

35. Mrs Dalloway, [1925] 2013: 159. “So it wasn't a failure after all! It was going to be alright now her party. It had begun, it had started."

36. Mrs Dalloway, [1925] 2013: 114-15 "But suppose Peter said to her, 'Yes, yes, but your parties what's the sense of your parties? All she could say was (and nobody could be expected to understand): They're an offering; which sounded horribly vague (...) It was an offering; to combine, to create; but to whom? An offering for the sake of offering, perhaps. Anyhow, it was her gift."

37. Mrs Dalloway, [1925] 2013: 111. "He could not tell he loved her. He held her hand. Happiness is this, he thought."

38. Mrs Dalloway, [1925] 2013: 69. "Whatever he took up he did in the same matter-of-fact sensible way; without a touch of imagination, without a spark of brilliancy; but with the inexplicable niceness of his time. He ought to have been a country gentleman - he was wasted on politics. He was at his best out of doors, with horses and dogs."

39. Mrs Dalloway, [1925] 2013: 69. "He was a thorough good sort; a bit limited; a bit thick in the head." 
40. Mrs Dalloway, [1925] 2013: 69. "He ought to have been a country gentleman - he was wasted on politics."

41. Mrs Dalloway, [1925] 2013: 156. "He should have stayed at home and read his book, thought Peter Walsh."

42. Mrs Dalloway, [1925] 2013: 113. "But suppose Peter said to her 'Yes, yes, but your parties what's the sense of your parties?"

43. Mrs Dalloway, [1925] 2013: 72. "She had a sense of comedy that was really exquisite, but she needed people, always people to bring it out, with the inevitable result that she fritted her time away, lunching, dining, giving these incessant parties of hers, talking nonsense, saying things she didn't mean."

44. Mrs Dalloway, [1925] 2013: 71. "With twice his wits, (Clarissa) had to see things through (Richard's) eyes - one of the tragedies of married life."

45. Mrs Dalloway, [1925] 2013: 36. "Yes, yes, yes," he muttered as he ran upstairs. "She will see me. After five years in India, Clarissa will see me."

46. Mrs Dalloway, [1925] 2013: 37. "Now of course, thought Clarissa, he's enchanting! Perfectly enchanting!"

47. Mrs Dalloway, [1925] 2013: 54. "It was at Bourton that summer, early in the 'nineties, when he was so passionately in love with Clarissa. There were a great many people there, laughing and talking, sitting round a table after tea."

48. Mrs Dalloway, [1925] 2013: 58. "His demands upon Clarissa (he could see it now) were absurd. He asked impossible things. He made terrible scenes. She would have accepted him still, perhaps, if he had been less absurd. Sally thought so. “

49. Mrs Dalloway, [1925] 2013: 59.

50. Mrs Dalloway, [1925] 2013: 178. "When I heard Clarissa was giving a party, I felt I couldn't not come - must see her again (and I'm staying in Victoria Street, practically next door). So I just came without an invitation."

51. Mrs Dalloway, [1925] 2013: 177. "What Sally felt was simply this. She had owed Clarissa an enormous amount. They had been friends, not acquaintances, friends."

52. Mrs Dalloway, [1925] 2013: 29. "They sat up till all hours of the night talking."

53. Mrs Dalloway, [1925] 2013: 66.

54. Mrs Dalloway, [1925] 2013: 170. "But everybody adored her (except perhaps Papa). It was her warmth; her vitality - she would paint, she would write. Old women in the village never to this day forgot to ask after "your friend in the red cloak who seemed so bright."

55. Mrs Dalloway, [1925] 2013: 176.

56. Mrs Dalloway, [1925] 2013: 30. "Sally's power was amazing, her gift, her personality (...) The charm was overpowering."

57. Mrs Dalloway, [1925] 2013: 31-32 "Then came the most exquisite moment of her whole life passing a stone urn with flowers in it. Sally stopped; picked a flower; kissed her on the lips. The whole world might have turned upside down! The others disappeared; there she was alone with Sally. And she felt she had been given a present, wrapped up, and told just to keep it, not to look at it - a diamond, something infinitely precious."

58. Mrs Dalloway, [1925] 2013: 29. "But this question of love (she thought putting her coat away), this falling in love with women. Take Sally Seton; her relation in the old days with Sally Seton. Had not that, after all, been love?" See also p. 31 "But nothing is so strange when one is in love (and what was this except being in love?).

59. Mrs Dalloway, [1925] 2013: 171.

60. Mrs Dalloway, [1925] 2013: 172. "Just as we were starting, my husband was called up on the telephone, a very sad case. A young man (that is what Sir William is telling Mr. Dalloway) had killed himself. He had been in the army." 
61. Mrs Dalloway, [1925] 2013: 172. “Oh! thought Clarissa, in the middle of my party, here's death. (...) What business had the Bradshaws to talk of death at her party - the Bradshaws talked of death. He had killed himself-but how? Always her body went through it first, when she was told, suddenly, of an accident; her dress flamed, her body burnt. He had thrown himself from a window. Up had flashed the ground; through him, blundering, bruising, went the rusty spikes. There he lay with a thud, thud, thud in his brain, and then a suffocation of blackness. So she saw it. But why had he done it?"

62. Mrs Dalloway, [1925] 2013: 180.

63. Mrs Dalloway, [1925] 2013: 174. "She felt somehow very like him - the young man who had killed himself. She felt glad that he had done it; thrown it away while they went on living."

64. Mrs Dalloway, [1925] 2013: 6 "She always had the feeling that it was very dangerous to live even one day."

65. Mrs Dalloway, [1925] 2013: 173. “There was the terror; the overwhelming incapacity, one's parents giving it into one's hands, this life, to be lived to the end, to be walked with serenely; there was in the depths of her heart an awful fear."

66. Mrs Dalloway, [1925] 2013: 172. "Death was defiance. Death was an attempt to communicate; people feeling the impossibility of reaching the centre, which mystically evaded them; closeness drew apart; rapture faded; one was alone. There was an embrace in death."

67. Mrs Dalloway, [1925] 2013: 173. "Somehow it was her disaster - her disgrace. It was her punishment to see sink and disappear here a man, there a woman, in this profound darkness, and she forced to stand here in her evening dress."

68. Mrs Dalloway, [1925] 2013: 173. "Odd, incredible; she had never been so happy. Nothing could be slow enough; nothing last too long."

69. Mrs Dalloway, [1925] 2013: 174. "But what an extraordinary night! She felt somehow very like him - the young man who had killed himself."

70. Mrs Dalloway, [1925] 2013: 1. "How fresh, how calm, stiller than this of course, the air was in the early morning; like the flap of a wave; the kiss of a wave."

71. Mrs Dalloway, [1925] 2013: 3. "I love walking in London," said Mrs. Dalloway. "Really, it's better than walking in the country."

72. Mrs Dalloway, [1925] 2013: 5. "But with Peter everything had to be shared; everything gone into. And it was intolerable, and when it came to that scene in the little garden by the fountain, she had to break with him or they would have been destroyed, both of them ruined, she was convinced."

73. Mrs Dalloway, [1925] 2013: 30. "Sally's power was amazing, her gift, her personality."

74. Mrs Dalloway, [1925] 2013: 30. "The strange thing, on looking back, was the purity, the integrity, of her feeling for Sally. It was not like one's feelings for a man. It was completely disinterested, and besides, it had a quality which could only exist between women, between women just grown up."

75. Mrs Dalloway, [1925] 2013: 56. "She was talking to a young man on her right. He had a sudden revelation. 'She will marry that man', he said to himself. He didn't even know his name. For of course it was that afternoon, that very afternoon that Dalloway had come over."

76. Mrs Dalloway, [1925] 2013: 56. "He was a prey to revelations at that time. This one - that he would marry Dalloway - was blinding, overwhelming at the moment."

77. Mrs Dalloway, [1925] 2013: 56 "He admired her courage; her social instinct; he admired her power of carrying things through."

78. Mrs Dalloway, [1925] 2013: 56. Peter later refers to Clarissa as "worldy" and "caring too much for rank and society." (70)

79. Mrs Dalloway, [1925] 2013: 109. "Here he was, in the prime of life, walking to his house in Westminster to tell Clarissa that he loved her." 
80. Mrs Dalloway, [1925] 2013: 108. "(He had grown) rather speechless, rather stiff - he repeated that it was a miracle, that he should have married Clarissa; a miracle - his life had been a miracle, he thought; hesitating to cross."

81. Mrs Dalloway, [1925] 2013: 111. "And it came over me 'I might have married you', she said, thinking of Peter sitting there in his little bow-tie."

82. Mrs Dalloway, [1925] 2013: 19-21. "He would shut his eyes, he would see no more. Leaves were alive; trees were alive (...) But no; there he was; still sitting alone on the seat, in his shabby overcoat, his legs crossed, staring, talking aloud. Men must not cut down trees. There is a God. (He noted such revelations on the backs of envelopes)."

83. Mrs Dalloway, [1925] 2013: 82. "Love between man and woman was repulsive to Shakespeare. The business of copulation was filth to him before the end. But Rezia said, she must have children. They had been married five years."

84. Mrs Dalloway, [1925] 2013: 63. "I leant over the edge of the boat and fell down, he thought. I went under the sea. I have been dead, and yet am now alive, but let me rest still; he begged."

85. Mrs Dalloway, [1925] 2013: 60. "Why should she suffer? she was asking, as she walked down the broad path."

86. Mrs Dalloway, [1925] 2013: 60. "She had been happy; she had had a beautiful home, and there her sister lived still, making hats."

87. Mrs Dalloway, [1925] 2013: 81. “'The English are so silent,' Rezia said. She liked it, she said. She respected these Englishmen, and wanted to see London, and the English horses, and the tailormade suits."

88. Mrs Dalloway, [1925] 2013: 82. "The English are so serious," she would say, putting her arms round Septimus, her cheek against his."

89. Mrs Dalloway, [1925] 2013: 127. "She was delighted to be free. The fresh air was so delicious. It had been so stuffy in the Army and Navy stores."

90. Mrs Dalloway, [1925] 2013: 180. "She was like a lily, Sally said, a lily by the side of a pool."

91. Mrs Dalloway, [1925] 2013: 126. "It was nice to be out in the air. People were beginning to compare her to poplar trees, early dawn, hyacinths, fawns, running water, and garden lilies; and it made life a burden to her, for she much preferred being left alone to do what she liked in the country, but they would compare her to lilies, and she had to go to parties, and London was so dreary compared with being alone in the country with her father and the dogs."

92. Mrs Dalloway, [1925] 2013: 167. "If only for Clarissa's health it would have been better to live in the country. But Clarissa had always been fond of society."

93. Mrs Dalloway, [1925] 2013: 109. "But why should she invite all the dull women in London to her parties?"

94. Mrs Dalloway, [1925] 2013: 178. "All these years the Dalloways had never been once. Time after time they had asked them. Clarissa (for it was Clarissa of course) would not come. For, said Sally, Clarissa was at heart a snob--one had to admit it, a snob."

95. Mrs Dalloway, [1925] 2013: 177. "What Sally felt was simply this. She had owed Clarissa an enormous amount."

96. Mrs Dalloway, [1925] 2013: 120. "It is the flesh, it is the flesh," she muttered (...) She prayed to God.

97. Mrs Dalloway, [1925] 2013: 116. "With all this luxury going on, what hope was there for a better state of things? Instead of lying on a sofa (...) she should have been in a factory; behind a counter; Mrs Dalloway and all the other fine ladies! (...) But Miss Kilman did not hate Mrs Dalloway (...) Miss Kilman felt, Fool! Simpleton! You who have known neither sorrow nor pleasure; you have trifled your life away."

98. Mrs Dalloway, [1925] 2013: 117. “This woman did nothing, believed nothing." 
99. Mrs Dalloway, [1925] 2013: 111. "And there is a dignity in people; a solitude; even between husband and wife a gulf; and that one must respect, thought Clarissa, watching him open the door."

100. Mrs Dalloway, [1925] 2013: 119. Adapted from "Why creeds and prayers and mackintoshes? When, thought Clarissa, that's the miracle, that's the mystery; that old lady she meant, whom she could see going from chest of drawers to dressing table. She could still see her (from the window). And the supreme mystery which Kilman might say she had solved, or Peter might say he had solved, but Clarissa didn't believe either of them had the ghost of an idea of solving, was simply this: here was the room; there another. Did religion solve that, or love?"

101. Mrs Dalloway, [1925] 2013: 83. "For the truth is (...) that human beings have neither kindness, nor faith, nor charity beyond what serves to increase the pleasure of the moment. They hunt in packs. Their packs scour the desert and vanish screaming into the wilderness. They desert the fallen."

102. Mrs Dalloway, [1925] 2013: 131. "The fallen, he said, they tear to pieces."

103. Mrs Dalloway, [1925] 2013: 60. "But for herself she had done nothing wrong; she had loved Septimus; she had been happy; she had had a beautiful home, and there her sister lived still, making hats. Why should she suffer?"

104. Mrs Dalloway, [1925] 2013: 60. “"No; I can't stand it any longer, she was saying, having left Septimus, who wasn't Septimus any longer, to say hard, cruel, wicked things, to talk to himself, to talk to a dead man, on the seat over there."

105. Mrs Dalloway, [1925] 2013: 62. "He dropped her hand. Their marriage was over, he thought, with agony, with relief. The rope was cut."

106. Mrs Dalloway, [1925] 2013: 64. "He knew all their thoughts, he said; he knew everything. He knew the meaning of the world, he said."

107. Mrs Dalloway, [1925] 2013: 80. "He developed manliness; he was promoted; he drew the attention, indeed the affection of his officer, Evans by name."

108. Mrs Dalloway, [1925] 2013: 80. Italics have been added for emphasis.

109. Mrs Dalloway, [1925] 2013: 82. "The last shells missed him. He watched them explode with indifference"

110. Mrs Dalloway, [1925] 2013: 82. "When Evans was killed, just before the Armistice, in Italy, Septimus, far from showing any emotion or recognising the end of a friendship, congratulated himself upon feeling very little and very reasonably."

111. Mrs Dalloway, [1925] 2013: 82. "For now that it was all over, truce signed, and the dead buried, he had, especially in the evening, these thunderclaps of fear."

112. Mrs Dalloway, [1925] 2013: 89. “'I have - I have,' he began, 'committed a crime - “ “

113. Mrs Dalloway, [1925] 2013: 89. “'He has done nothing wrong whatever,' Reza assured the doctor."”

114. Mrs Dalloway, [1925] 2013: 82. "They were proud of him; he had won crosses. 'You've done your duty; it is up to us-"'.

115. Mrs Dalloway, [1925] 2013: 89. 'Yes, he served with the greatest distinction,' Reza assured the doctor."”

116. Mrs Dalloway, [1925] 2013: 80. "He had gone through the whole show, friendship, European War, death, had won promotion, was still under thirty and bound to survive".

117. Mrs Dalloway, [1925] 2013: 82. "But he himself remained high on his rock, like a drowned sailor on a rock. I leant over the edge of the boat and fell down, he thought. I went under the sea. I have been dead and yet am now alive, but let me rest still, he begged (he was talking to himself again - it was awful, awful!"

118. Mrs Dalloway, [1925] 2013: 82. "There were moments of waking in the early morning. The bed was falling; he was falling." 
119. Mrs Dalloway, [1925] 2013: 86. "Dr Homes was such a kind man. He was so interested in Septimus."

120. Mrs Dalloway, [1925] 2013: 84. "Now he had surrendered; now other people must help him (...) Dr. Holmes. What a kind man."

121. Mrs Dalloway, [1925] 2013: 85. "If Dr. Holmes found himself even half a pound below eleven stone six, he asked his wife for another plate of porridge at breakfast. (Rezia would learn to cook porridge)."

122. Mrs Dalloway, [1925] 2013: 85. "Once you stumble, Septimus wrote on the back of a postcard, human nature is on you. Holmes is on you."

123. Mrs Dalloway, [1925] 2013: 86. "Holmes had won of course; the brute with the red nostrils had won."

124. Mrs Dalloway, [1925] 2013: 61. "He would argue with her about killing themselves; and explain how wicked people were; how he could see them making up lies as they passed in the street. He knew all their thoughts, he said, he knew everything. He knew the meaning of the world, he said."

125. Mrs Dalloway, [1925] 2013: 86. "So he was deserted. The whole world was clamouring: Kill yourself, kill yourself for our sakes. But why should he kill himself for their sakes?"

126. Mrs Dalloway, [1925] 2013: 86. "But Rezia could not understand him. Dr Holmes was such a kind man.

127. Mrs Dalloway, [1925] 2013: 86. "It was at that moment (Rezia had gone shopping) that the great revelation took place. A voice spoke from behind the screen. Evans was speaking. The dead were with him. 'Evans, Evants!' he cried." Also “'Evans!' he cried. There was no answer. “ (136);

"'Evans, Evans, Evans - his messages from the dead; do not cut down the trees; tell the Prime Minister"'. (138)

128. Mrs Dalloway, [1925] 2013: 87. "Now what's all this about,' said Dr. Holmes in the most amiable way in the world. 'Talking nonsense to frighten your wife?"'

129. Mrs Dalloway, [1925] 2013: 138 "'Evans, Evans, Evans - his messages from the dead; do not cut down the trees; tell the Prime Minister".

130. Mrs Dalloway, [1925] 2013: 86. "Mr. Smith was talking aloud to himself, Agnes the girl servant cried to Mrs. Filmer in the kitchen. 'Evans, Evans!' he had said as she brought in the tray."

131. Mrs Dalloway, [1925] 2013: 78. "London has swallowed up many millions of young men called Smith; thought nothing of fantastic Christian names like Septimus with which their parents have thought to distinguish them (...) But of all this what could the most observant of friends have said except what a gardener says when he opens the conservatory door in the morning and finds a new blossom on his plant: - It has flowered; flowered from vanity, ambition, idealism, passion, loneliness, courage, laziness, the usual seeds, which all muddled up, made him shy, and stammering, made him anxious to improve himself."

132. Mrs Dalloway, [1925] 2013: 86. "But even Holmes himself could not touch this last relic straying on the edge of the world, this outcast, who gazed back at the inhabited regions, who lay, like a drowned sailor, on the shore of the world."

133. Mrs Dalloway, [1925] 2013: 87. "You brute! You brute!" cried Septimus, seing human nature, that is Dr. Holmes, enter the room."

134. Mrs Dalloway, [1925] 2013: 87. "Now what's all this about,' said Dr. Holmes in the most amiable way in the world. 'Talking nonsense to frighten your wife?' But he would give him something to make him sleep. And if they were rich people, said Dr. Holmes, looking ironically round the room, by all means let them go to Harley Street; if they had no confidence in him, said Dr. Homes, looking not quite so kind."

135. Mrs Dalloway, [1925] 2013: 87-88. "the ghostly helper, the priest of science (...) the stream of patient being so incessant (...) gave him the reputation of the utmost importance in dealing with nerve cases." 
136. Mrs Dalloway, [1925] 2013: 88.

137. Mrs Dalloway, [1925] 2013: 88

138. Mrs Dalloway, [1925] 2013: 87-88. "For often Sir William would travel sixty miles or more down into the country to visit the rich, the afflicted, who could afford the very large fee which Sir William very properly charged for his advice. Her ladyship waited with the rugs about her knees an hour or more, leaning back, thinking sometimes of the patient, sometimes, excusably, of the wall of gold, mounting minute by minute while she waited."

139. Mrs Dalloway, [1925] 2013: 88.

140. Mrs Dalloway, [1925] 2013: 88-89. "It was a case of complete breakdown-complete physical and nervous breakdown, with very symptom in an advanced stage, he ascertained in two or three minutes."

141. Mrs Dalloway, [1925] 2013: 89. "Her husband was very seriously ill, Sir William said. Did he threaten to kill himself?"

142. Mrs Dalloway, [1925] 2013: 91. "But if he confessed? If he communicated? Would they let him off then, Holmes and Bradshaw? 'I-I- ' he stammered. But what was his crime? He could not remember it. 'Yes?' Sir William encouraged him. (But it was growing late.). Love, trees, there is no crime - what was his message? He could not remember it. 'I-I- 'Septimus stammered."

143. Mrs Dalloway, [1925] 2013: 89-90. "It was merely a question of rest, said Sir William; of rest, rest, rest; a long rest in bed. There was a delightful home down in the country where her husband would be perfectly looked after."

144. Mrs Dalloway, [1925] 2013: 92. "Health we must have (...) so that when a man comes into your room and says he is Christ (...) you invoke proportion; order rest in bed; rest in solitude; silence and rest; rest without friends, without books, without messages; six months' rest."

145. Mrs Dalloway, [1925] 2013: 94-95. "For example, Lady Bradshaw. Fifteen years ago she had gone under. It was nothing you could put your finger on; there had been no scene, no snap; only the slow sinking, waterlogged, of her will into his. Sweet was her smile, swift was her submission (...) Now, quick to minister to the craving which lit her husband's eye so oilily for dominion, for power (...) Naked, defenceless, the exhausted, the friendless received the impress of Sir William's will. He swooped; he devoured. He shut people up. It was his combination of decision and humanity that endeared Sir William so greatly to the relations of his victims."s

146. Mrs Dalloway, [1925] 2013: 94-95. "Naked, defenceless, the exhausted, the friendless received the impress of St William's will. He swooped, he devoured. He shut people up. It was this combination of decision and humanity that endeared Sir William so greatly to the relations of his victims."

147. Mrs Dalloway, [1925] 2013: 130. "Fear no more, says the heart in the body; fear no more. He was not afraid."

148. Mrs Dalloway, [1925] 2013: 139-40. "It was their idea of tragedy (...) Holmes and Bradshaw. (...) Holmes was at the door. 'I'll give it to you!' he cried, and flung himself vigorously, violently down on to Mrs. Filmer's area railings."

149. Mrs Dalloway, [1925] 2013: 139-40. 'The coward!' cried Dr. Holmes, bursting the door open. Rezia ran to the window, she saw; she understood (...) Who could have foretold it? A sudden impulse, no one was in the least to blame (he told Mrs. Filmer). And why the devil he did it, Dr. Holmes could not conceive."

150. Mrs Dalloway, [1925] 2013: 64.

151. Mrs Dalloway, [1925] 2013: 64.

152. Mrs Dalloway, [1925] 2013: 182. "He had looked at her, he said, and had wondered, Who is that lovely girl? And it was his daughter!"

153. Mrs Dalloway, [1925] 2013: 180. "Indeed, the young are beautiful, Sally said, watching Elizabeth cross the room." 
154. Mrs Dalloway, [1925] 2013: 173 "Odd, incredible; she had never been so happy. Nothing could be slow enough; nothing last too long. "In Woolf's original text, the feeling is directly experienced by Clarissa Dalloway.

155. Mrs Dalloway, [1925] 2013: 2. "Big Ben strikes. There! Out it boomed. First a warning, musical; then the hour, irrevocable."

156. Virginia Woolf, The Common Reader- Notes on an Elizabethan Play ([1925] 1984: 52].

157. A phrase that Woolf originally applied to Montaigne in The Common Reader: "We can never doubt for an instant that his book was himself (...) All his effort was to write himself down, to communicate, to tell the truth." (Woolf, [1925] 1984: 59).

158. Mrs Dalloway [1925] 2013: 80.

159. Mrs Dalloway [1925] 2013: 31-32.

160. Virginia Woolf, The Common Reader- Modern Fiction ([1925] 1984: 149).

161. 3 students were native speakers of English. There were also 6 European students visiting from Ukraine, Poland, Austria, and Switzerland on the ERASMUS + program. The seminar defines itself as multimodal, with traditional classes held in regular teaching rooms, and workshops organized in multimedia labs or studios at the Arts Centre (Maison des Arts).

162. Melissa Blanc and I wish to thank Laurence Apert et Idyl Bagga-Petit - who respectively teach German and English at Lycée Bossuet, Condom (Gers) - for their kind invitation. We also wish to express admiration for their pedagogical engagement and superb organizational skills. News article : https://lejournaldugers.fr/article/27644-les-langues-par-corps

163. "Life is not a series of gig lamps symmetrically arranged; life is a luminous halo, a semitransparent envelope surrounding us from the beginning of consciousness to the end." Virginia Woolf, The Common Reader- Modern Fiction ([1925] 1984: 150].

164. Mrs Dalloway, [1925] 2013: 2.

165. Frequent reference is made to children in Woolf's novel, most of the time negatively. Septimus and his wife Reza, in particular, are obsessed with the presence of children playing boisterously outdoors: "sky and tree, children playing, dragging carts, blowing whistles, falling down; all were terrible." Mrs Dalloway, [1925] 2013: 20.

\section{INDEX}

Subjects: Dance

Mots-clés: chorégraphie, chœur tragique, guerre, homo-érotisme, réécriture créative, transposition, Woolf

Keywords: choreography, chorus, creative rewriting, homoeroticism, transposition, war, Woolf

\section{AUTHORS}

\section{JEAN-RÉMI LAPAIRE}

Professeur

EA CLIMAS / Université Bordeaux Montaigne

jrlapaire@u-bordeaux-montaigne.fr 